\title{
Kremeňovo-karbonátové žily s U-Mo-Cu mineralizáciou v permských intermediárnych až bázických vulkanitoch hronika na lokalite Kravany (Kozie chrbty, východné Slovensko)
}

\author{
Quartz-carbonate veins containing U-Mo-Cu mineralization in the Permian \\ intermediate to basic volcanic rocks of the Hronicum Unit at Kravany \\ (Kozie Chrbty Mts., eastern Slovakia)
}

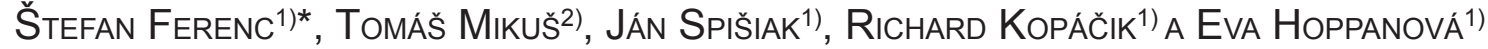 \\ ${ }^{1)}$ Katedra geografie a geológie, Fakulta prírodných vied, Univerzita Mateja Bela, Tajovského 40, 97401 Banská \\ Bystrica, Slovenská republika; *e-mail: stefan.ferenc@umb.sk \\ 2) Ústav vied o Zemi, Slovenská akadémia vied, Ďumbierska 1, 97411 Banská Bystrica, Slovenská republika
}

Ferenc Š, Mikuš T, SpIŠIAK J, KopÁčIK R, Hoppanová E (2020) Kremeňovo-karbonátové žily s U-Mo-Cu mineralizáciou $v$ permských intermediárnych až bázických vulkanitoch hronika na lokalite Kravany (Kozie chrbty, východné Slovensko). Bull Mineral Petrolog 28(2): 364-384 ISSN 2570-7337

\begin{abstract}
Historical uranium ore deposit Kravany is located in the eastern part of Kozie Chrbty Mts., approximately $9 \mathrm{~km}$ $\mathrm{SW}$ of the district town Poprad. Stratiform, infiltration U-Cu-Pb mineralization is bound to the Upper Permian clastic sediments (Kravany Beds, member of Malužiná Formation, Hronicum Unit), which are enriched in fragments of carbonized flora. Vein U-Mo-Cu mineralization was found in the Upper Permian intermediate to basic volcanics intersecting the sediments of the Kravany Beds (also ore lenses). Vein filling originated in the following development stages: I.) Quartz-pyrite (quartz, pyrite, marcasite), II.) Dolomite-pyrite (dolomite, pyrite, marcasite, galena), III.) Copper (tetrahedrite, tennantite, chalcopyrite), IV.) Uranium-molybdenum (uraninite, Pb-Mo-S phase, coffinite, quartz), and V.) Calcite (calcite, chalcopyrite). The formation of mineralization can be explained by the geological position: random emplacement of the diorite porphyrite, resp. basalt-andesite dikes, directly in the preexisting U,Mo-bearing sediments. Vein U-Mo-Cu mineralization could thus most likely have formed according to the following scenario: I.) sedimentation of Kravany Beds in the Permian riftogenic basin: formation of beds of arkoses and arkosic sandstones with abundant fragments of charred flora, II.) formation of infiltration $U$ mineralization: reduction and accumulation of $\mathrm{U}$ in sediments rich in organic matter, III.) emplacement of dikes of intermediate to basic volcanics: intersection of sediments with organics and with high $U$ and Mo content, mobilization of formation fluids, assimilation of $U$ and Mo into intermediate-basic magma, IV.) cooling of volcanic bodies $\rightarrow$ their contraction (formation of contraction cracks) $\rightarrow$ filling of contraction cracks with quartz, carbonates and ore minerals (crystallization from residual magmatic solutions mixed with formation waters). From this point of view it is syngenetic volcanogenic vein U-Mo-Cu mineralization, originally of the Permian age, with subsequent Alpine (most probably Cretaceous) reworking (this is evidenced by the variable composition of uraninite). It belongs to the Neohercynian late- to postorogenic metallogenetic stage. The possible younger, post-Permian age of mineralization from alpine hydrothermal solutions must also be assumed, but this consideration has several inconsistencies.
\end{abstract}

Key words: uraninite, molybdenite, remobilization, volcanogenic deposit, volcanic rocks, Permian, Hronic Unit, Western Carpathians

Obdrženo 21. 10. 2020; prijiato 7. 12. 2020

\section{Úvod}

Ložisko uránových (d’alej U) rúd Kravany je súčast’ou pásma malých historických U ložísk a ložiskových, respektíve mineralogických výskytov vo východnej časti Kozích chrbtov - Dúbrave (predtým Vikartovský chrbát). Okrem Kravan ide najmä o lokality Vikartovce, Spišská Teplica - Vysová, Švábovce a Spišský Štiavnik. Stratiformná, infiltračná $U$, respektíve U-Cu-Pb mineralizácia, v minulosti ekonomického významu, je $v$ Dúbrave via- zaná na vrchnopermské klastické sedimenty (kravanské vrstvy), ktoré sú obohatené úlomkami zuhol'natenej flóry.

Mineralogickou a metalogenetickou zaujímavostou lokality Kravany je neekonomická, žilná U-Mo-Cu mineralizácia, zistená vo vrchnopermských intermediárnych až bázických vulkanitoch pretínajúcich sedimenty kravanských vrstiev (Ferenc 2002). Predložený príspevok je venovaný detailnej mineralogickej charakteristike tohto zrudnenia a problematike jeho genézy. 


\section{Geologická stavba širšieho okolia}

Východná čast' Kozích chrbtov - Dúbrava tvorí výraznú morfologickú eleváciu $\mathrm{V}-\mathrm{Z}$ smeru, zo $\mathrm{S}$ a J markantne zlomovo oddelenú od Podtatranskej a Hornádskej kotliny. Z hl'adiska morfológie sú Dúbrava a pril'ahlá čast' Hornádskej kotliny (Vikartovská priekopa) pomerne mladé celky, ktoré sa vytvorili na rozhraní pliocénu a pleistocénu vertikálnymi pohybmi pozdíž V-Z zlomov (Fusán et al. 1963; Maglay et al. 1999).

Horský chrbát Dúbravy je budovaný mladopaleozoickými až vrchnotriasovými horninami tektonickej jednotky hronika (obr. 1). V oblasti hlavného hrebeňa, severne

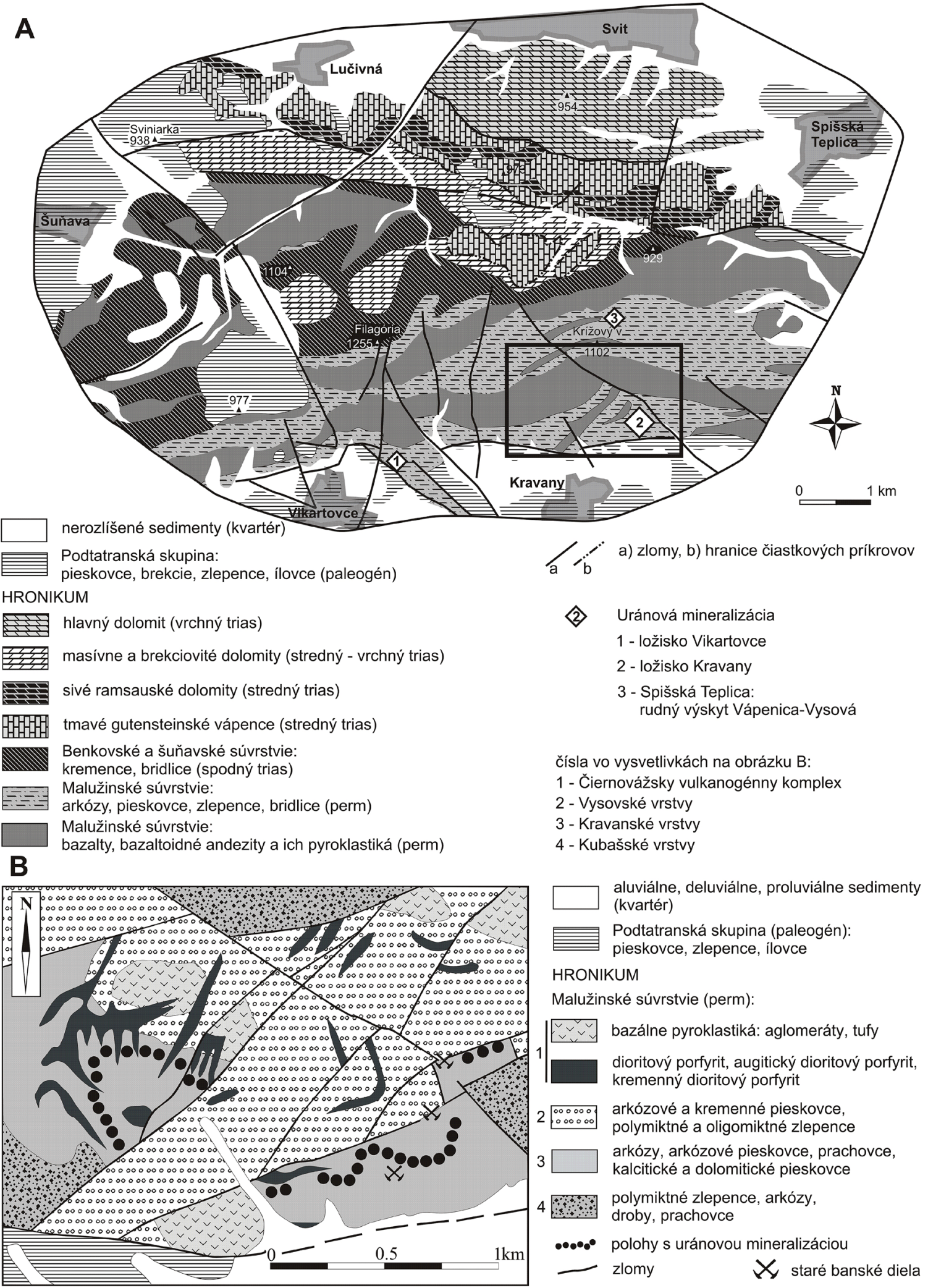

Obr. 1A) Geologická stavba východnej časti Kozích chrbtov - Dúbravy v území medzi Svitom a Vikartovcami (podla: Biely et al. 1992) s vyznačením výskytov U-Cu mineralizácie. B) Detailná schéma geologickej stavby ložiska Kravany (podla: Badár, Novotný 1970 in Tulis, Novotný 1998). 
od Vikartoviec a Kravan vystupuje vulkanosedimentárny komplex vrchnopermského malužinského súvrstvia (Vozárová, Vozár 1988). Klastické sedimenty sú reprezentované najmä pestrými (červené, fialové, sivé, zelenosivé) pieskovcami s polohami červených bridlíc a prachovcov. Na zlomoch smeru SV-JZ sú lokálne v pieskovcoch vyvinuté kremenné ( \pm karbonáty, \pm baryt) žily s Cu mineralizáciou (Ferenc, Kuruc 2015). Výraznou črtou tejto oblasti sú mohutné telesá a dajky bázických až intermediárnych vulkanitov (bazaltoidné andezity, bazalty a ich pyroklastiká). Vulkanity predstavujú súčast' rozsiahlejšieho kontinentáIneho riftu v pôvodnej vrchnokarbónsko - permskej panve a majú tholeiitický trend (napr. Vozár 1977; Dostal et al. 2003; Vozár et al. 2015). Známe sú predovšetkým kvôli výskytom $\mathrm{SiO}_{2}$ mineralizácie. Na mnohých miestach sa v bazaltoch vyskytuje tiež impregnačná Cu mineralizácia, alebo barytové ( \pm karbonáty, \pm kremeň) žily s Cu zrudnením (Ferenc, Rojkovič 2001; Olšavský, Ferenc 2002).

\section{Geologicko-ložisková charakteristika ložiska Kravany}

Historické ložisko U rúd Kravany leží asi 1300 m smerom na SV od Kravan (okres Poprad), v priestore kóty 905 m, 1200 m na JJV od Krížového vrchu (kóta 1102 m), asi $700 \mathrm{~m}$ na $\mathrm{S}$ od cesty spojujúcej Kravany a Spišské Bystré. Geografické koordináty centra ložiska sú: N: $49^{\circ}$ 0‘28.9“; E: 20 12“40.7“"

Ložisko sa t’ažilo štôlňami č. 34 a 17 v období rokov 1968 - 1970, pričom bilančné rudy boli vytažené. V tomto období sa z tunajších rúd získalo 25494.6 kg kovového uránu (Tulis, Novotný 1998). Priemerný obsah U v rudách z Kozích chrbtov (Vikartovce, Švábovce, Spišský Štiavnik) je $0.64 \mathrm{hm}$. \%, na lokalite Vikartovce bol zistený maximálny obsah U 21.49 hm. \% v bodovej vzorke (Rojkovič 1997). Priemerný obsah $U$ $v$ rudách $z$ ložiska Kravany sa pohyboval v rozmedzí 0.13 - 0.39 hm. \% (Tulis, Novotný 1998).

\section{Priame nadložie permské-} ho vulkanosedimentárneho komplexu tvoria kremence a kremenné arkózy spodnotriasového benkovského súvrstvia (sp. trias - skýt), nad ktorými sa nachádza šuňavské súvrstvie (sp. trias - spat) tvorené prevažne ílovitými bridlicami, menej vápnitými pieskovcami a vápencami (obr. 1A). Stredný až vrchný trias je zastúpený karbonátovým vývojom (rôzne typy dolomitov a vápencov). Vrchný trias reprezentujú najmä hlavné dolomity s polohami ílovcov a bridlíc lunzského súvrstvia, ktoré budujú masív Baby a Smolníka pri Svite (Biely et al. 1992).

Paleogénne formácie podtatranskej skupiny (Biely et al. 1997) tvoria výplň Podtatranskej a Hornádskej kotliny (obr. 1A). Vystupujú tu dve litostratigrafické jednotky: borovské súvrstvie (brekcie, zlepence, pieskovce, vápence) a tiež monotónne hutianske súvrstvie s prevahou ílovcov.

Kvartérne sedimenty sú reprezentované akumuláciami náplavových kužel'ov pri vyúst'ovaní dolín z Dúbravy do okolitých kotlín. Triasové a paleogénne podložie Popradskej kotliny je z vel'kej miery zakryté akumuláciami glacifluviálnych sedimentov. $\checkmark$ údoliach súčasných tokov sa akumulujú sedimenty dolinných nív, v okolí Svitu a Spišskej Teplice sa tiež nachádzajú rašeliniská a menšie výskyty pramenitov (Biely et al. 1997).
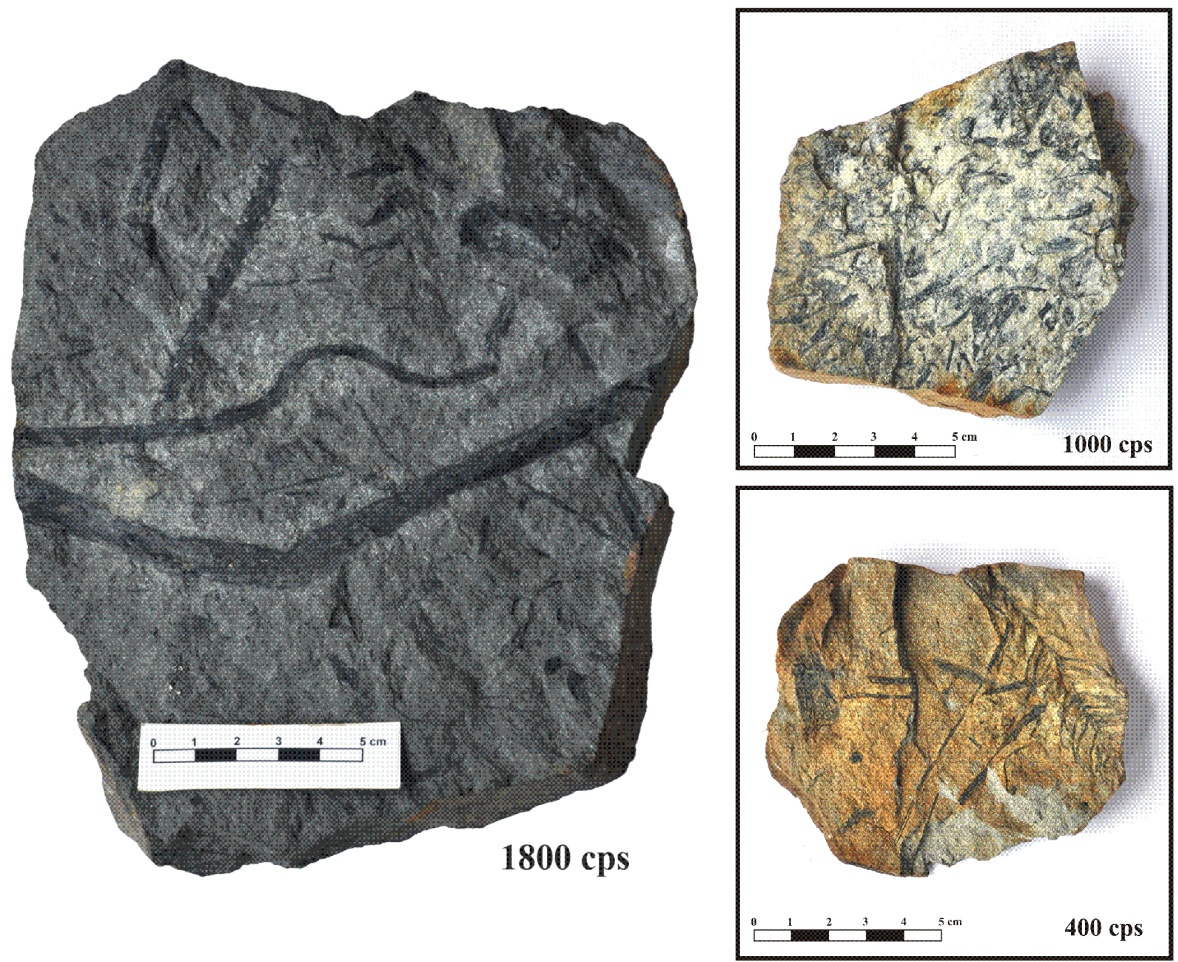

Obr. 2 Ukážky uránovej rudy z lokality Kravany. Väčšina zuholnatených fragmentov rastlín je deformovaná, vzácne sa nájdu aj nedeformované zvyšky (pravdepodobne Lebachia piniformis, vpravo dole). Foto: R. Kopáčik.

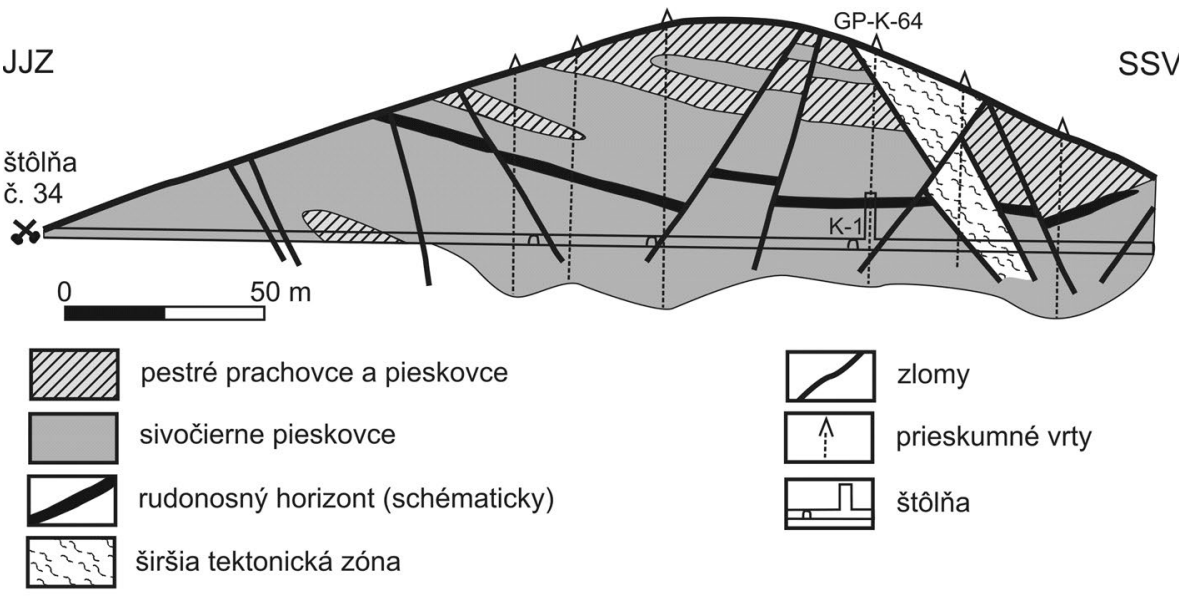

Obr. 3 Profil ložiskom U rúd v Kravanoch (podla: Šváb, Ferenc 1969 in Veselý, Badár 1984). 
Stratiformná, infiltračná uránová mineralizácia je lokalizovaná $v$ klastických sedimentoch vrchnopermských kravanských vrstiev (súčast' malužinského súvrstvia; obr. 1B). Produktívny horizont je tvorený jemno- až strednozrnnými arkózami (resp. arkózovými pieskovcami) s vložkami piesčitých vápencov. Charakteristická je prítomnost' zuhol'nateného rastlinného detritu (obr. 2). Klastické sedimenty sú pretínané menšími telesami permských paleoandezitov, paleobazaltov a príslušných vulkanoklastík. Podložie produktívneho horizontu tvorí súvrstvie polymiktných zlepencov, drôb a menej arkóz. $\checkmark$ nadloží produktívneho horizontu sa nachádzajú priamo paleogénne horniny podtatranskej skupiny (eocén), reprezentované jemnozrnnými polymiktnými zlepencami a arkózami s lokálnymi polohami ílovcov (Novotný, Badár 1971; Veselý, Badár 1984). Súvrstvia ložiska sú epizonálne metamorfované. Na základe pozorovaní katagenetických štádií vývoja zuhol'natenej flóry, kryštalinity illitu a štúdia fluidných inklúzií možno odvodit' híbku ich pochovania najmenej $2 \mathrm{~km}$, a teplotu metamorfného pretvorenia $100-150{ }^{\circ} \mathrm{C}$, pravdepodobne na konci paleozoika, respektíve $v$ ranom mezozoiku (Rojkovič et al. 1992; Šucha, Eberl 1992).

V priestore ložiska je vyvinutý jeden horizont zrudnených šošovkovitých telies tmavošedých psamitov so zuhol'natenými úlomkami flóry. Vo vzdialenosti $5 \mathrm{~m} v$ jeho nadloží sa nachádza d'alší horizont, avšak len ojedinelých šošoviek. Uloženie rudného horizontu je monoklinálne so sklonmi $10^{\circ}$ až $25^{\circ} \mathrm{k}$ VSV, lokálne je porušený zlomovou tektonikou poklesovo-prešmykového charakteru $\mathrm{s}$ amplitúdou 5 - $10 \mathrm{~m}$ (obr. 3). Na južnom okraji lokality (v blízkosti vikartovského zlomu) sú rudonosné vrstvy intenzívne zvrásnené.

Rudné šošovky majú väčšinou nepravidelné, laločnaté tvary a generálne sú pretiahnuté v smere SSV-JJZ. Ich zoskupenie $v$ ploche vývoja vytvára pruh tohto smeru široký $50-80 \mathrm{~m}$.

Maximálna dížka jednotlivých šošoviek je do $30 \mathrm{~m}$, ich šírka varíruje od 2 do $21 \mathrm{~m}$ a hrúbka sa spravidla pohybuje okolo $1 \mathrm{~m}$

V zlome smeru SV-JZ (úklon $50^{\circ}-70^{\circ} \mathrm{k}$ JV) lokalizovanom na SV od vlastnej lokality bol zistený odlišný typ mineralizácie. Výplň zlomovej štruktúry tvoria jemnoaž strednozrnné arkózové pieskovce/arkózy. Uránové zrudnenie tvorilo $v$ rámci tektonickej zóny polohu hrubú $20-90 \mathrm{~cm}$. Táto poloha bola intenzívne obohatená organickou hmotou, pričom bola sekundárne mineralizovaná kremeňom a karbonátmi (Veselý, Badár 1984).

$\mathrm{Na}$ ložisku Kravany boli zistené nasledujúce minerálne fázy: uraninit, coffinit, pyrit, chalkopyrit, tennantit, tetraedrit, galenit, sfalerit, arzenopyrit, bornit, markazit, molybdenit, kremeň, kalcit, dolomit, autunit, uranofán, uránové černe, azurit, malachit, chryzokol a goethit. Mineralizácia je vel'mi jemnozrnná, viazaná najmä do polôh bohatých na zuhol'natený rastlinný detrit (Rojkovič 1974; Ferenc et al. 2003). Cu sulfidická mineralizácia, okrem jemnozrnných impregnácií v hornine vystupuje aj v drobných kremenno-karbonátových žilkách. $\mathrm{V}$ telesách vulkanitov a zlomových štruktúrach má U-Cu mineralizácia ojedinele žilno-žilníkovú formu.

Mineralizácia má silnú väzbu na organickú hmotu humínového typu. Zdrojový materiál organickej hmoty predstavovali zvyšky terestrických vyšších rastlín, ktoré neprekonali dlhší transport. Za zdroj uránu sú považované klasty granitoidov a metamorfovaných hornín veporického kryštalinika. Organika (na báze rašeliny alebo lignitu) slúžila ako geochemická bariéra pre cirkulujúce roztoky s obsahom $U$ (redukcia $U^{6+}$ na $U^{4+}$, zníženie mobility a koncentrácia tohto prvku). K tomuto procesu pravdepodobne dochádzalo $v$ pripovrchových podmienkach, pred intenzívnou gelifikáciou organickej hmoty. Po čiastočnej litifikácii boli počas ranoalpínskych orogénnych udalostí zuhol'natené zvyšky rastlín fraktúrované, niekedy lokálne vrásnené. Vzniknuté puklinky boli sekundárne vyplnené kremenno-karbonátovo-sulfidickou mineralizáciou, ktorá často preráža staršiu stratiformnú U mineralizáciu. Nízkoteplotné hydrotermálne roztoky tiež zapríčinili čiastočnú remobilizáciu U a tvorbu mladšej uraninitovo-sulfidickej mineralizácie (Rojkovič et al. 1992; Rojkovič 1997).

Stratiformná uránová mineralizácia $v$ Kravanoch je permského veku. U-Pb datovaním uraninitu boli zistené veky 263 - 274 miliónov rokov, zodpovedajúce guadalupskej epoche (Legierski in Rojkovič 1997).

\section{Metodika}

Vzorky pre mineralogické štúdium boli odobraté z blízkosti zvyškov rudnej haldy, pomocou rádiometra $\mathrm{R}$ 511 [cps]. Zo vzoriek boli následne vyhotovené leštené výbrusy a nábrusy za účelom mikroskopického štúdia v prechádzajúcom aj odrazenom svetle. Jedna vzorka $s$ identickou mineralizáciou pochádzala zo starších zberov prof. I. Rojkoviča.

Chemické zloženie jednotlivých minerálov (okrem uraninitu) bolo zist'ované pomocou elektrónového mikroanalyzátora Jeol-JXA-8530F (Ústav vied o Zemi SAV, Banská Bystrica). Mikroanalyzátor sa využil pri orientačnom sledovaní chemického zloženia minerálov prostredníctvom energiovo-disperzného spektra (EDS) a pre bodové vlnovodisperzné mikroanalýzy (WDS). WDS mikroanalýzy sa robili za týchto podmienok: urýchl'ovacie napätie $15 \mathrm{kV}$, merací prúd $16 \mathrm{nA}$ (karbonáty), urýchl'ovacie napätie 20 $\mathrm{kV}$, merací prúd $15 \mathrm{nA}$ (sulfidy a sulfosoli). Priemer elektrónového lúča sa pohyboval v rozmedzí 2 - $8 \mu \mathrm{m}$, použila sa ZAF korekcia. Analyzovali sa nasledovné prvky (kryštál, rtg. línie) za použitia týchto štandardov: Ag (PETL, La) - Ag, Fe (LIFL, Ka) - pyrit, Sb (PETL, La) - antimonit, Hg (PETL, Ma) - cinabarit, As (TAP, L $\beta$ ) - GaAs, arzenopyrit, $\mathrm{Se}(\mathrm{TAP}, \mathrm{L} \beta)-\mathrm{Bi}_{2} \mathrm{Se}_{3}, \mathrm{Bi}(\mathrm{PETH}, \mathrm{M \alpha})-\mathrm{Bi}_{2} \mathrm{~S}_{3}, \mathrm{Cu}$ (LIFH, $\mathrm{Ka}$ ) - chalkopyrit, $\mathrm{Ni}$ (LIFH, Ka) - gersdorffit, Co (LIFH, Ka) - Co, S (PETJ, Ka) - pyrit, Zn (LIF, Ka) - sfalerit, Cd (PETJ, La) - CdTe, Pb (PETJ, Ma) - galenit, Au (PETH, $M \alpha)-A u, M n(L I F H, K \alpha)$ - rodonit, Ca (PETL, Ka) - diopsid, Ba (PETL, La) - baryt, Mn (LIFL, Ka) - rodonit, Na (TAP, $\mathrm{Ka}$ ) - albit, Mg (TAP, Ka) - diopsid, Al (TAP, Ka) - albit, Si (TAP, Ka) - plagioklas $\mathrm{An}_{65}$, Fe (LIFH, Ka) - hematit, Sr (PETH, La) - celestín. Detekčný limit pre jednotlivé prvky sa pohyboval v rozsahu $0.003-0.03 \mathrm{hm}$. \%. Fotodokumentácia minerálov a ich vzájomných mikroštruktúrnych vzt'ahov bola urobená v režime spätne rozptýlených elektrónov (BSE) na tom istom prístroji.

Datovanie uraninitu (Montel et al. 1996) bolo urobené na elektrónovom mikroanalyzátore Cameca SX100 v Štátnom geologickom ústave Dionýza Štúra v Bratislave (analyzoval: P. Konečný). Pri meraní sa použili nasledovné podmienky: urýchl'ovacie napätie $15 \mathrm{kV}$, merací prúd 80 - $150 \mathrm{nA}$, čas merania 75 - $130 \mathrm{~s}$, priemer elektrónového lúča $1-5 \mu \mathrm{m}$. Štandardy a spektrálne čiary: CuFeS $(\mathrm{SK} \alpha)$, galenit $(\mathrm{PbM} \alpha)$, hematit (FeKa), $\mathrm{UO}_{2}(\mathrm{UM} \beta), \mathrm{ThO}_{2}$ (ThMa), apatit (PKa), GaAs 2 (AsL $\alpha)$, wollastonit (SiKa, CaKa), korund (AlKa), $\mathrm{YPO}_{4}(\mathrm{YL \alpha}), \mathrm{CePO}_{4}(\mathrm{CeL} \alpha), \mathrm{LaPO}_{4}$ (LaL $\alpha), \mathrm{GdPO}_{4}(\mathrm{GdL} \alpha), \mathrm{YbPO}_{4}(\mathrm{YbL \alpha}), \mathrm{TbPO}_{4}(\mathrm{TbL} \alpha)$, $\mathrm{TmPO}_{4}(\mathrm{TmL} \alpha), \mathrm{SmPO}_{4}(\mathrm{SmL} \beta), \mathrm{PrPO}_{4}(\mathrm{PrL} \beta), \mathrm{ErPO}_{4}$ 
$(\mathrm{ErL} \beta), \mathrm{NdPO}_{4}(\mathrm{NdL} \beta), \mathrm{LuPO}_{4}(\mathrm{LuL} \beta), \mathrm{HoPO}_{4}(\mathrm{HoL} \beta)$, $\mathrm{EuPO}_{4}(\mathrm{EuL} \beta)$ a $\mathrm{DyPO}_{4}(\mathrm{DyL} \beta)$. Pri interferenciách najmä prvkov vzácnych zemín boli použité nasledovné korekcie: $\mathrm{Pb}$ x Y 0.008029, U x Th 0.00704, Gd x La 0.017352, Gd $x$ Ce 0.073999, Er x Gd (0.027983, Lu x Yb 0.03688, Lu x Dy 0.051522, Ho x Gd 0.017001, Lu x Ho 0.068289, Eu x Dy 0.12, Er x Eu 0.022131 a Tm x Sm 0.11517. Detekčný limit pre jednotlivé prvky sa pohyboval $v$ rozsahu 0.01 0.09 hm. \%. Prvky s obsahom pod detekčný limit nie sú zahrnuté v tabul'kách.

Autorádiografia vzoriek bola urobená v svetlotesnej krabici na ortochromatický film (Orto-CP-G plus). Doba expozície vzorky dokumentovanej v tomto príspevku bola dva dni.

\section{Výsledky}

\section{Charakter mineralizácie}

Relikty rudnej haldy sa nachádzajú mimo priestoru vlastného ložiska, na lúke, asi $400 \mathrm{~m}$ na JZ od západného vchodu štôlne č. 34. Na tomto mieste je možné nájst' úlomky kremenno-karbonátovej žiloviny (kremeň-kalcitdolomit) vo vulkanických horninách s minerálmi U, Mo, $\mathrm{Cu}$ a $\mathrm{Fe}$. Na základe vel'kosti úlomkov možno predpokladat', že maximálna hrúbka žil je zhruba $10-15 \mathrm{~cm}$.

Nerudná výplň mineralizovaných štruktúr je tvorená bielymi a ružovými karbonátmi, ktoré výrazne prevládajú nad kremeňom. Textúra žiloviny je často brekciovitá, kar- bonáty a kremeň tmelia úlomky hostitel'ského, alterovaného vulkanitu (obr. 4a).

Uraninit vystupuje $v$ tesnej priestorovej asociácii $\mathrm{s} \mathrm{Pb}-\mathrm{Mo}-\mathrm{S}$ minerálnou fázou. Tvoria čierne vlásočnicové žilky (lokálne hrúbka max. 2 - 3 mm) s dížkou 10 - 12 $\mathrm{cm} \vee$ karbonátoch, jemnozrnné impregnácie $v$ okolných horninách, respektíve $v$ ich fragmentoch uzavieraných žilnou výplňou (obr. 4b), vzácne masívnejšie akumulácie (vel'kost' do $1 \mathrm{~cm}$ ), alebo tmavé, šmuhovité akumulácie (vel'kost' do $3 \mathrm{~cm}$ ) v miestach zvýšeného obsahu pyritu $\checkmark$ žilovine. Minerály Cu (tetraedrit-tennantit, chalkopyrit) a pyrit sú $v$ žilách zastúpené podradne, vo forme chudobných vtrúsenín. Pyrit však zriedkavo tvorí aj bohatšie akumulácie.

\section{Hostitel'ská hornina}

Študovaná mineralizácia sa nachádza v alterovaných, afanitických žilných intermediárnych až bázických vulkanitoch tmavosivej až čiernej farby (vrchný perm).

Hornina je zložená prevažne z plagioklasov dvoch generácií. Menej zastúpený plagioklas I tvorí relatívne vel'ké $(0.5 \times 0.15 \mathrm{~mm})$ porfyrické výrastlice, zatial' čo plagioklas II sa podstatnou mierou podiel'a na stavbe horninového matrixu. Dížka jeho kryštálov sa priemerne pohybuje okolo 0.1 mm, pri hrúbke 15 - $20 \mu \mathrm{m}$ (obr. 5a). Hydrotermálne procesy spôsobili čiastočnú, alebo úplnú premenu plagioklasov na zmes sericitu a iných ílových minerálov. V hornine sú hojne roztrúsené alotriomorfné zrná (vel'kost' 10 - 15
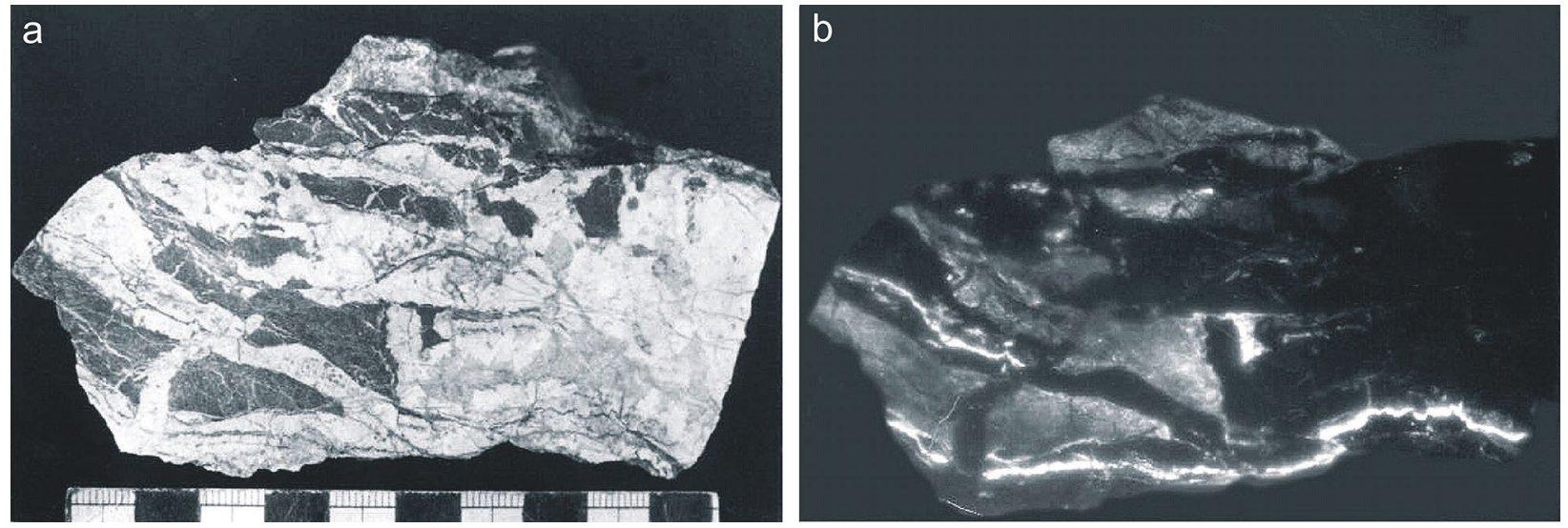

Obr. 4 a) Typická kremenno-karbonátová žilovina s U-Mo-Cu mineralizáciou. Aktivita 580 - 610 cps. b) Autorádiogram vzorky, čas expozície 2 dni. Foto: L. Osvald.
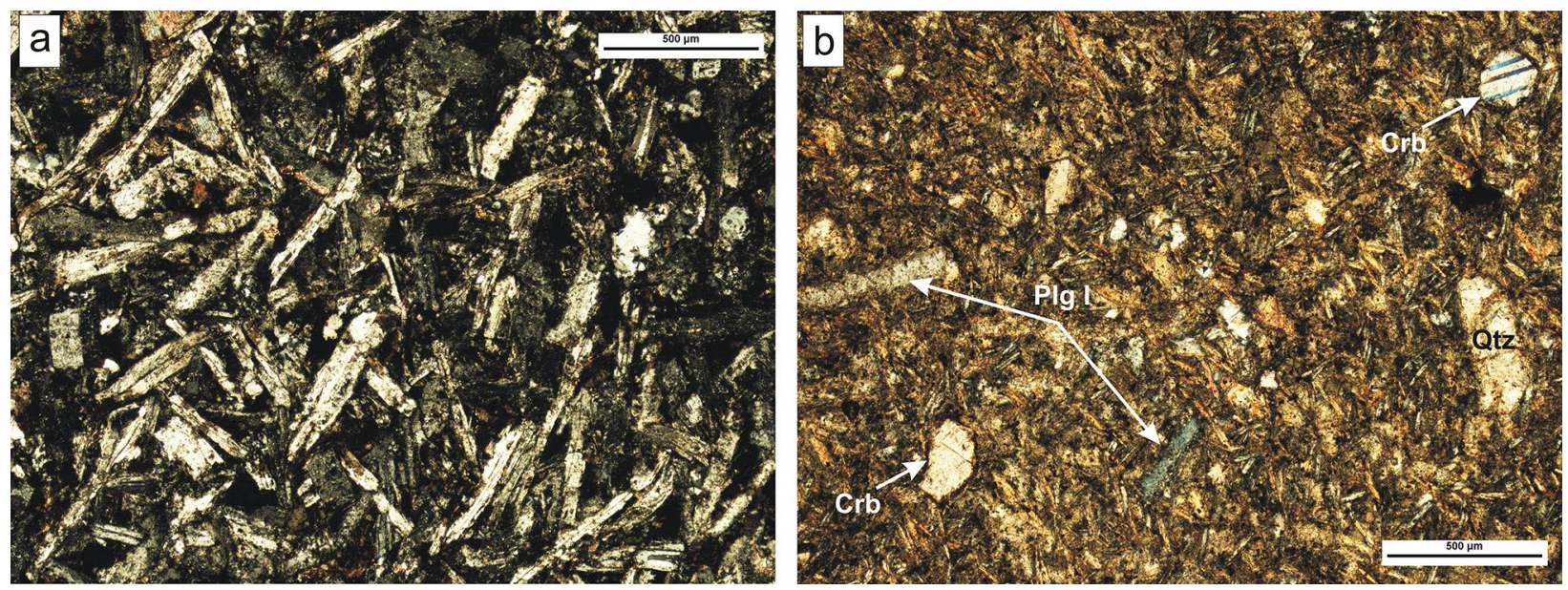

Obr. 5 a) Alterovaná vulkanická hornina tvorená hlavne plagioklasmi I. generácie. b) Amygdaloidné dutiny v hornine sú vyplínané kremeňom (Qtz) a karbonátmi (Crb). Vel'ké výrastlice sú plagioklasy I. generácie (Plg I). Prechádzajúce svetlo, XPL. Foto: Š. Ferenc. 
$\mu \mathrm{m})$ leukoxenizovaných Fe-Ti oxidov. Puklinky v hornine (hrúbka do $0.03 \mathrm{~mm}$ ) sú vyhojené Fe-chloritmi. Drobné amygdaloidné dutiny (vel'kost' do $1 \mathrm{~mm}$ ) sú vyplnené kremeňom, alebo karbonátmi (obr. 5b). Pyrit je $v$ hornine vtrúsený iba sporadicky (neskoro, resp. postmagmatický pyrit I). Jeho vznik možno spájat' s kryštalizáciou zvyško-
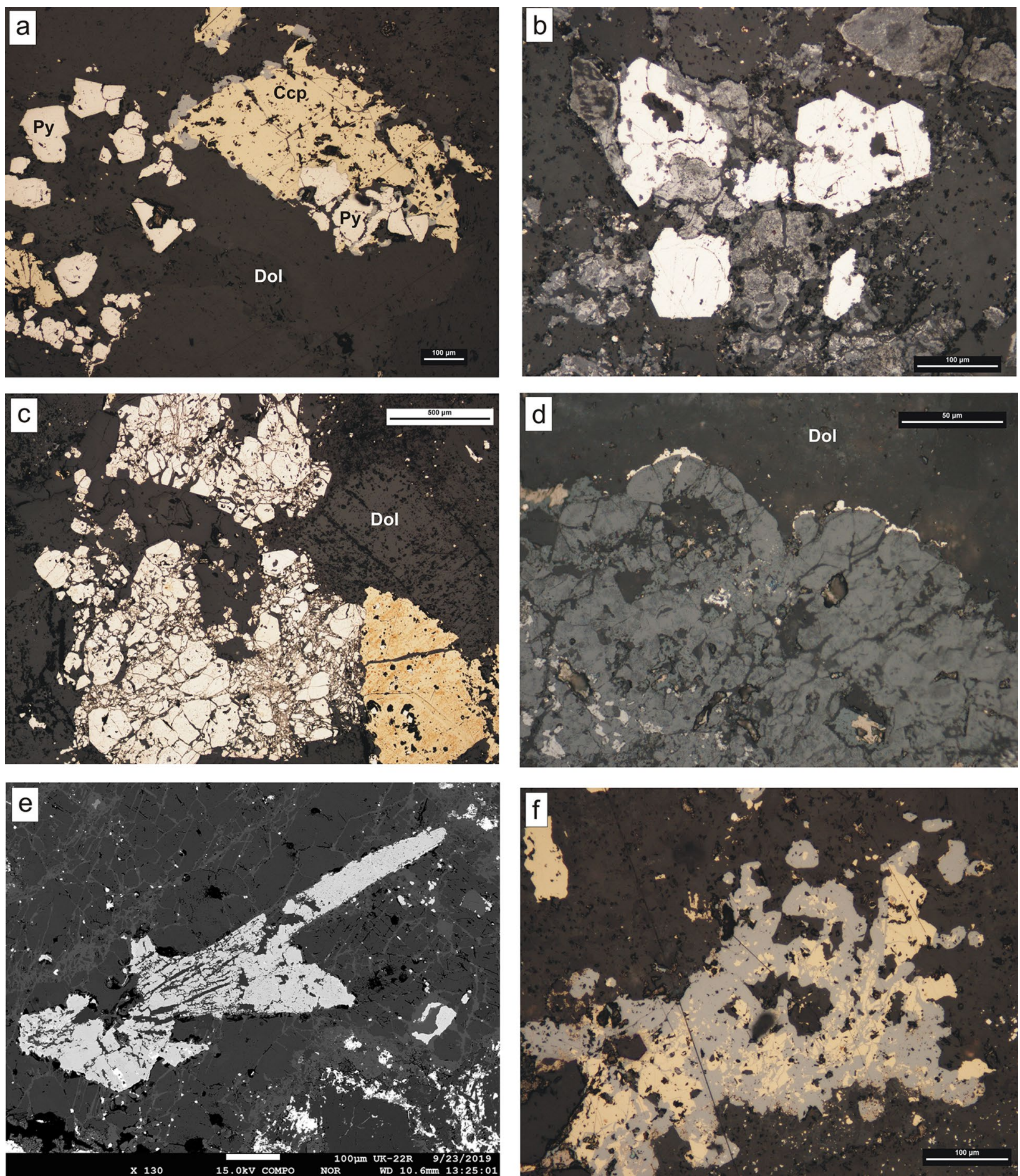

Obr. 6 a) Alotriomorfné až hypidiomorfné kryštály pyritu III sú uzavierané v chalkopyrite (Ccp). Puklinky v pyritových kryštáloch sú miestami vyhojené tennantitom (sivý), ktorý tvorí vlásočnicové žilky v chalkopyrite, resp. nan̆ nasadá. Okolie tvorí dolomit (Dol). b) Pyrit III (biely) je obrastaný U-Mo mineralizáciou. Uraninit (tmavosivý) sa prerastá s Pb-Mo-S minerálnou fázou (svetlosivá). Okolie tvorí dolomit (takmer čierne). c) Kataklázované agregáty pyritu III (biely) $v$ asociácii s chalkopyritom (žltý) v dolomite (Dol). d) Uraninit (tmavosivý) obrastá Pb-Mo-S minerálnu fázu (svetlosivá, hlavne vlavo dole). L'advinovitý povrch uraninitu je lemovaný pyritom IV. e) Relikt agregátu prizmatických kryštálov markazitu (sivobiely) korodovaný dolomitom (tmavosivý). Biele, nepravidelné zhluky (vpravo dole) sú minerály $\mathrm{Pb}$ a U. f) Chalkopyrit (žltý) obrastaný tennantitom (sivý). Okolie je tvorené dolomitom. Obr. e urobený v BSE režime (foto: T. Mikuš), ostatné obrázky v odrazenom svetle pri PPL (foto: Š. Ferenc). 


\section{Opis minerálov}

\section{Rudné minerály}

Pyrit je najhojnejší sulfidický (postmagmatický, hydrotermálny) minerál $v$ žilovine. Jeho najstaršia generácia (pyrit II) zriedkavo tvorí idiomorfné kryštáliky vel'ké zhruba $5 \mu \mathrm{m} v$ kremeni I. Najrozšírenejší je pyrit III, vytvárajúci idiomorfné kryštáliky (hexagonálny prierez) až alotriomorfné zrná (vel'kost' do $1 \mathrm{~mm}$, priemerne $\sim 0.1 \mathrm{~mm}$ ) a ich agregáty $\mathrm{v}$ dolomite. Lokálne prerastá $\mathrm{s}$ markazitom, býva obrastený chalkopyritom a tennantitom (obr. 6a) a U-Mo minerálmi (obr. 6b). Vzácne boli v pyrite III zistené vtrúseniny galenitu. Agregáty kryštálov pyritu III sú niekedy intenzívne kataklázované (obr. 6c), puklinky sú miestami vyhojené chalkopyritom a/alebo minerálmi tetraedritovo-tennantitového radu. Pyrit IV tvorí tenké žilky na rozhraní kalcitových žiliek s horninou, respektíve na rozhraní kalcitových žiliek $s$ karbonátmi $v$ amygdaloidných dutinách horniny. Niekedy lemuje l'advinovité agregáty uraninitu a vyplńa $v$ ňom puklinky (obr. $6 d$ ). Študované bolo chemické zloženie pyritu III (tab. 1), ktorý je generáIne charakteristický malým obsahom prímesí. Výraznejšie (ale ojedinele) bol v ňom zistený zvýšený obsah Bi (do 2.04 hm. \%; 0.01 apfu), As (do 0.68 hm. \%; 0.03 apfu) a Au $(0.11 \mathrm{hm}$. \%). Priemerný empirický vzorec pyritu III je $\mathrm{Fe}_{0.99}\left(\mathrm{~S}_{1.99} \mathrm{As}_{0.01}\right)_{\Sigma 2.00}$. V odrazenom svetle (polarizačný mikroskop) prejavovali niektoré agregáty a kryštály pyritu III anomálnu anizotropiu, ktorá môže byt' spôsobená defektmi v štruktúre minerálu pri jeho tlakovom namáhaní $v$ iniciálnej fáze ( $v$ pokročilej fáze došlo až ku katakláze zŕn, tieto „kataklazity“ však neboli anizotropné).

Markazit je pomerne vzácne zastúpený. Bol zistený v agregátoch zŕn pyritu III, kde tvorí zrná a lamely vel'ké do $50 \mu \mathrm{m}$. Jeho drobné zrná (vel'kost' $10-15 \mu \mathrm{m}$ ) tvoria miestami zhluky vel'ké do $0.5 \mathrm{~mm} v$ dolomite, niekedy masívnejšie agregáty markazitu obrastajú pyrit III. Len ojedi-

Tabul'ka 1 Chemické zloženie pyritu III (Py) a markazitu (Mar) z Kravan

\begin{tabular}{lrrrrrr}
\hline & 1 & 2 & 3 & 4 & 5 & 6 \\
\hline $\mathrm{Fe}$ & $\mathrm{Py}$ & $\mathrm{Py}$ & $\mathrm{Py}$ & $\mathrm{Py}$ & $\mathrm{Py}$ & Mar \\
$\mathrm{Ni}$ & 0.00 & 0.01 & 0.00 & 0.01 & 0.00 & 0.01 \\
$\mathrm{Co}$ & 0.05 & 0.06 & 0.08 & 0.07 & 0.06 & 0.11 \\
$\mathrm{Cu}$ & 0.07 & 0.02 & 0.01 & 0.03 & 0.00 & 0.02 \\
$\mathrm{As}$ & 0.50 & 0.34 & 0.01 & 0.00 & 1.68 & 0.00 \\
$\mathrm{Sb}$ & 0.00 & 0.01 & 0.02 & 0.02 & 0.01 & 0.03 \\
$\mathrm{Bi}$ & 0.00 & 0.00 & 2.04 & 0.90 & 0.75 & 0.07 \\
$\mathrm{Au}$ & 0.00 & 0.00 & 0.09 & 0.11 & 0.10 & 0.00 \\
$\mathrm{~S}$ & 52.57 & 53.03 & 52.97 & 53.29 & 51.62 & 52.97 \\
\hline $\mathrm{Swt.} \%$ & 98.92 & 99.12 & 101.07 & 100.48 & 99.86 & 99.35 \\
\hline atómové koeficienty & $($ prepočet & $3 \mathrm{3}$ atómy) & & & \\
\hline $\mathrm{Fe}$ & 0.996 & 0.990 & 0.991 & 0.992 & 0.999 & 0.999 \\
$\mathrm{Ni}$ & 0.000 & 0.000 & 0.000 & 0.000 & 0.000 & 0.000 \\
$\mathrm{Co}$ & 0.001 & 0.001 & 0.002 & 0.001 & 0.001 & 0.002 \\
$\mathrm{Cu}$ & 0.001 & 0.000 & 0.000 & 0.001 & 0.000 & 0.000 \\
$\mathrm{As}$ & 0.008 & 0.005 & 0.000 & 0.000 & 0.027 & 0.000 \\
$\mathrm{Sb}$ & 0.000 & 0.000 & 0.000 & 0.000 & 0.000 & 0.000 \\
$\mathrm{Bi}$ & 0.000 & 0.000 & 0.012 & 0.005 & 0.004 & 0.000 \\
$\mathrm{Au}$ & 0.000 & 0.000 & 0.001 & 0.001 & 0.001 & 0.000 \\
$\mathrm{~S}$ & 1.994 & 2.003 & 1.994 & 2.000 & 1.967 & 1.998 \\
\hline $\mathrm{Fe} / \mathrm{S}$ & 0.50 & 0.49 & 0.50 & 0.50 & 0.51 & 0.50 \\
\hline & & & & & &
\end{tabular}

nele boli v dolomite pozorované jeho prizmatické kryštály dlhé do $1 \mathrm{~mm}$ (obr. 6e), zrejme ide o staršiu generáciu markazitu. Jeho chemické zloženie je blízke empirickému vzorcu $\mathrm{FeS}_{2}$ (tab. 1), vel'mi mierne je zvýšený iba obsah Co $(0.11 \mathrm{hm} . \%)$.

Galenit je pomerne vzácnym minerálom. Mikroskopické vtrúseniny galenitu boli zistené v kryštáloch pyritu III (obr. 7b). Miestami vytvára alotriomorfné zrná (vel'kost' do $30 \mu \mathrm{m})$ v dolomite, na okraji žiliek U-Mo minerálov. Chemické zloženie galenitu bolo zist'ované iba orientačne. Podl'a neštandardizovaných EDS analýz neobsahuje žiadne prímesi.

Chalkopyrit je v rámci Cu mineralizácie rozšírenejší než minerály tetraedritovo-tennantitového radu. $V$ dolomite s nimi obyčajne tvorí nepravidelné agregáty (vel'kost' do $1 \mathrm{~mm}$ ), alebo vystupuje aj samostatne. Z hl'adiska mikroštruktúrneho vzt'ahu medzi chalkopyritom, tennantitom a tetraedritom boli zistené jeho dve generácie. Chalkopyrit I býva uzavieraný minerálmi tetraedritovo-tennnantitového radu (obr. 6a,f), zatial' čo málo rozšírený chalkopyrit II na nich tvorí lemy hrubé do $3 \mu \mathrm{m}$ (obr. 7a). Chalkopyrit I uzaviera kryštály pyritu III, sám je zatláčaný/pretínaný tetraedritom, tennantitom, uraninitom, coffinitom a Pb-Mo-S minerálnou fázou.

Z minerálov tetraedritovej skupiny je absolútne dominantný tennantit-(Fe). Vystupuje $v$ dolomite, kde s chalkopyritom väčšinou tvorí nepravidelné agregáty (max. 1 $\mathrm{mm}$ vel'ké), alebo vystupuje aj samostatne. Mikroštruktúrne vzt'ahy s chalkopyritom, respektíve aj s inými minerálmi sú opísané vyššie. Tetraedrit-(Fe) bol zistený len ojedinele, tvorí zrná vel'ké do $20 \mu \mathrm{m}$ obrastené tennantitom-(Fe) (obr. 7b). Chemické zloženie minerálov tetraedritovej skupiny je ilustrované tabul'kou 2 a obrázkom 8 . V študovaných mineráloch tetraedritovo-tennantitového radu sa najvýraznejšie uplatňuje substitúcia $A s \leftrightarrow S b$, na pozícii (S1) $\mathrm{D}$ (v zmysle všeobecného vzorca ${ }^{\mathrm{M} 2} \mathrm{~A}_{6}{ }^{\mathrm{M} 1}\left(\mathrm{~B}_{4} \mathrm{C}_{2}\right)^{\mathrm{X} 3} \mathrm{D}_{4}{ }^{\mathrm{S} 1} \mathrm{Y}_{12}{ }_{12}^{\mathrm{S} 2} \mathrm{Z}$; sensu Biagioni et al. 2020). Obsah As $\vee$ tennantite-(Fe) kolíše $v$ rozmedzí $12.72-18.21 \mathrm{hm}$. \% (2.63 - 3.64 apfu). Zistený obsah As v tetraedrite-(Fe) je 9.17 hm. \% (1.97 apfu). Kolísanie pomeru tetraedritovej (Td) a tennantitovej (Tn) zložky v skúmaných minerálnych fázach možno $z$ tohto hl'adiska vyjadrit' ako $\mathrm{Tn}_{90} \mathrm{Td}_{10}$ - $\operatorname{Td}_{51} \mathrm{Tn}_{49}$. Pozície ${ }^{\mathrm{M} 2} A$ a ${ }^{\mathrm{M} 1} B$ sú obsadené takmer výlučne $\mathrm{Cu}$, pri zanedbatel'nom obsahu Ag. Pozícia ${ }^{\mathrm{M} 1} \mathrm{C}$ je v tennantite-tetraedrite obsadená hlavne dominantným Fe (4.27 7.17 hm. \%; 1.23 - 1.92 apfu), ktoré je sčasti nahrádzané Zn $(0.77-3.35$ hm. \%; 0.18 - 0.77 apfu). Obsah ostatných prímesí v tejto pozícii je bezvýznamný (tab. 2). Charakteristický je systematicky znížený obsah S v pozíciách ${ }^{\mathrm{S} 1} Y \mathrm{a}^{\mathrm{S} 2} \mathrm{Z}$ (spolu priemerne $27.15 \mathrm{hm}$. \%; $12.87 \mathrm{apfu}$ ), čo indikuje prítomnost' vakancií $v$ štruktúre minerálu na pozícii ${ }^{\mathrm{S}} Z$.

Uraninit je jedným z najhojnejších rudných minerálov. Charakteristická je jeho úzka priestorová i genetická spätost' s Pb-Mo-S minerálnou fázou. Ich makroskopické vystupovanie je opísané v kapitole „Charakter mineralizácie“. V rámci kremenno-kalcitovo-dolomitovej žiloviny sú oba obmedzené na dominantný, starší dolomit. V mikroskopickej mierke sa uraninit niekedy koncentruje na okraji žiliek $\mathrm{Pb}-\mathrm{Mo}$-S minerálu (ale na spoločných štruktúrach), obyčajne však 
S touto fázou intímne prerastá. V samostatných žilkách tvorí globulárne agregáty $\mathrm{s}$ radiálnou štruktúrou, vel'ké maximálne $50 \mu \mathrm{m}$ (obr. 7c). Puklinky v takýchto agregátoch, respektíve priestory medzi nimi, sú vyplínané coffi-
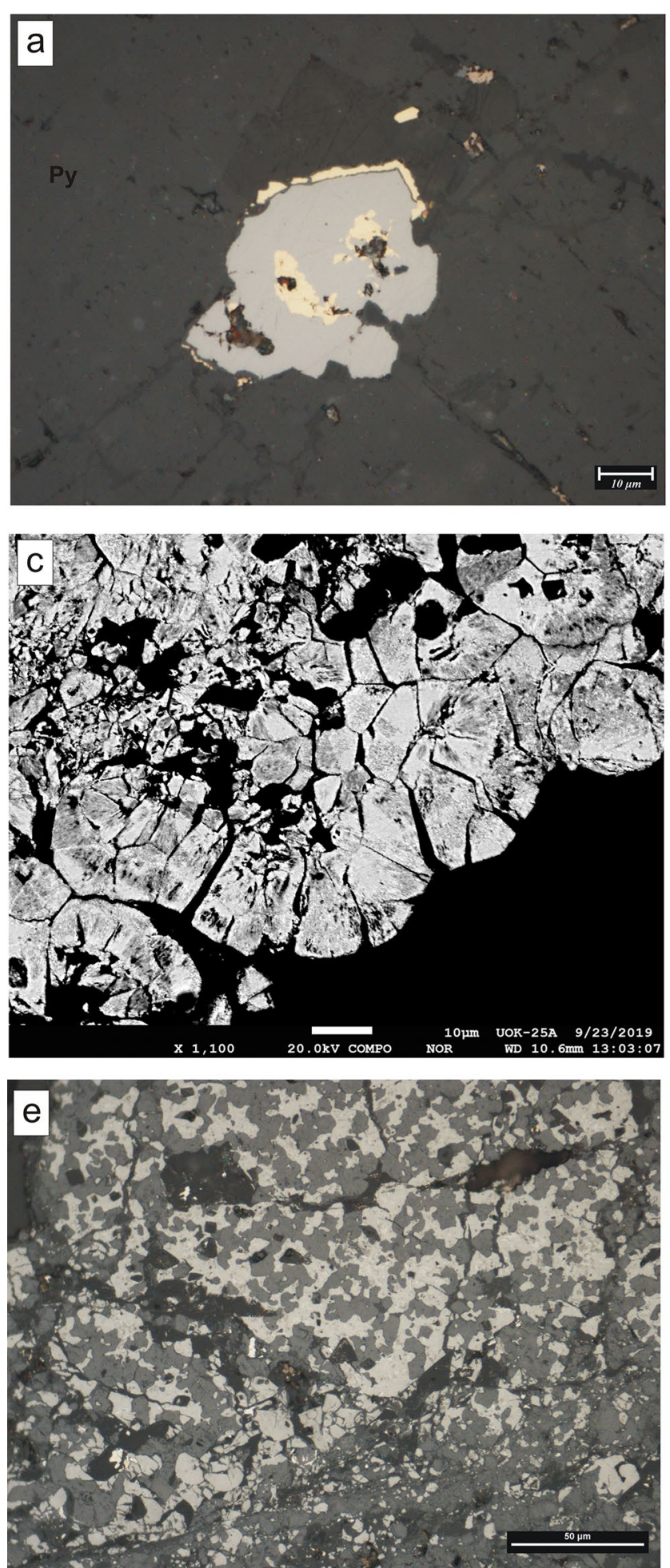

nitom (obr. 7d); ich okraje sú lokálne lemované pyritom IV (obr. 6d). Vzájomné vzt'ahy uraninitu a Pb-Mo-S minerálnej fázy sú vel'mi komplikované. Čast' uraninitu je kogenetická s Pb-Mo-S minerálom, o čom v niektorých
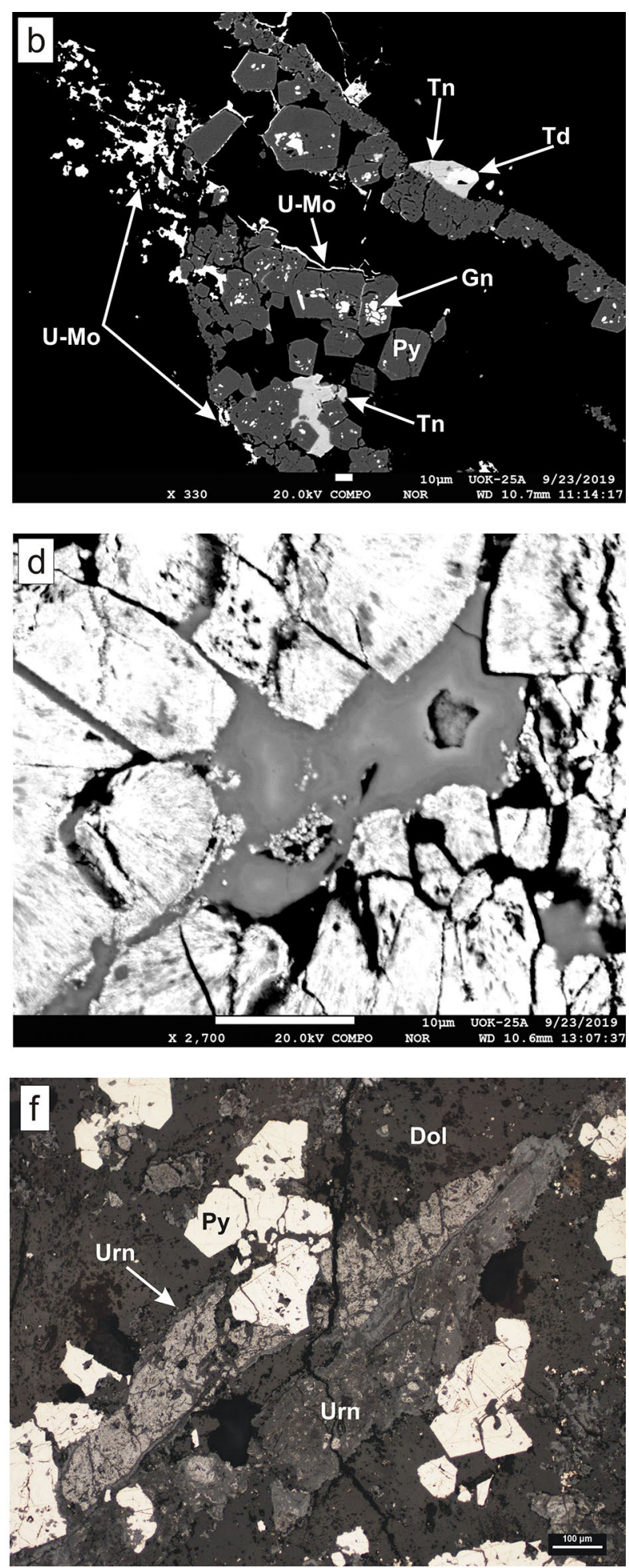

Obr. 7 a) Tennantit (sivý) uzaviera chalkopyrit I, zatial' čo sám je obrastaný druhou generáciou chalkopyritu (chalkopyrity sú žlté). Okolie (sivočierne) je tvorené dolomitom. b) Žilky a agregáty hypidiomorfných kryštálov pyritu (Py) obsahujú inklúzie galenitu (Gn). Sami sú obrastané tennantitom $(T n)$ a tetraedritom $(T d)$, tiež aj lemami a nepravidelnými hniezdami U-Mo minerálov (U-Mo). Okolie (čierne) tvorí dolomit. c) L'advinovité agregáty uraninitu (sivobiele až sivé) miestami s radiálnou štruktúrou. d) Coffinit (tmavosivý) vyplína puklinky a dutinky v uraninite (biely). e) Prerastanie uraninitu (tmavosivý) a Pb-Mo-S fázy (svetlosivá). f) Pyritové agregáty (Py) obrastané Pb-Mo-S minerálnou fázou. Táto sa nachádza v kontakte s uraninitom (Urn), ktorý ju aj obrastá. Rôzne odtiene tmavosivej farby uraninitu sú zapríčinené jeho rôznymi generáciami (mladšie generácie sú svetlejšie). Obrázky a, e, f sú urobené v odrazenom svetle, PPL (foto: Š. Ferenc); ostatné obrázky sú urobené v BSE režime (foto: T. Mikuš). 
prípadoch svedčia rovnovážne mikrotextúry ich agregátov (obr. 7e), čast' uraninitu je však mladšia, pretože samostatné žilky $\mathrm{Pb}-\mathrm{Mo}-\mathrm{S}$ minerálu sú obtekané mladšími generáciami uraninitu (obr. 7f). Pb-Mo-S minerálna fáza je však čiastočne tiež mladšia ako čast' uraninitu. Dokumentujú to šošovky (vel'kost' max. 70 - $100 \mu \mathrm{m}$ ), kedy uraninitové jadro je lemované Pb-Mo-S minerálom, za vzniku zaujímavých očkatých mikrotextúr. Tieto šošovky sú vždy súčast'ou väčších akumulácií uraninitu a Pb-Mo-S minerálu (obr. 9a,b), v ktorých posledne menovaný tvorí aj žilky vo viacerých generáciách uraninitu. Jednotlivé generácie uraninitu sú zhruba rozpoznatel'né podl'a rozdielnej odraznosti. Prechody $v$ doménach $s$ rozdielnou odraznost'ou sú však často difúzne a navyše pozorovanie $v$ odrazenom svetle je skomplikované prítomnost'ou coffinitu a intímnym prerastaním uraninitu s Pb-Mo-S fázou. Približný (či konečný) počet generácií uraninitu nie je možné určit'. Niekol'konásobná remobilizácia uraninitu

Tabul'ka 2 Mikroanalýzy tennantitu (Tn) a tetraedritu (Td) z Kravan

\begin{tabular}{|c|c|c|c|c|c|c|c|c|c|c|c|}
\hline & 1 & 2 & 3 & 4 & 5 & 6 & 7 & 8 & 9 & 10 & 11 \\
\hline & $\mathrm{Tn}$ & $\mathrm{Tn}$ & $\mathrm{Tn}$ & $\mathrm{Tn}$ & $\mathrm{Tn}$ & $\mathrm{Tn}$ & $\mathrm{Tn}$ & $\mathrm{Tn}$ & Tn & $\mathrm{Tn}$ & $\mathrm{Td}$ \\
\hline $\mathrm{Cu}$ & 42.34 & 42.64 & 42.08 & 42.71 & 41.14 & 41.90 & 42.10 & 42.09 & 41.87 & 41.56 & 39.71 \\
\hline $\mathrm{Ag}$ & 0.01 & 0.02 & 0.03 & 0.01 & 0.03 & 0.07 & 0.12 & 0.04 & 0.04 & 0.03 & 0.12 \\
\hline $\mathrm{Mn}$ & 0.07 & 0.02 & 0.05 & 0.06 & 0.08 & 0.07 & 0.06 & 0.02 & 0.07 & 0.05 & 0.04 \\
\hline $\mathrm{Fe}$ & 7.08 & 7.17 & 5.17 & 5.76 & 5.41 & 6.76 & 6.65 & 4.65 & 4.41 & 5.27 & 4.27 \\
\hline $\mathrm{Zn}$ & 0.77 & 0.88 & 2.99 & 2.05 & 2.57 & 0.83 & 0.96 & 3.35 & 3.21 & 2.36 & 3.25 \\
\hline $\mathrm{Cd}$ & 0.00 & 0.02 & 0.04 & 0.00 & 0.05 & 0.00 & 0.00 & 0.02 & 0.00 & 0.00 & 0.00 \\
\hline $\mathrm{Hg}$ & 0.01 & 0.00 & 0.04 & 0.04 & 0.08 & 0.05 & 0.05 & 0.00 & 0.02 & 0.00 & 0.02 \\
\hline $\mathrm{Pb}$ & 0.04 & 0.15 & 0.04 & 0.00 & 0.02 & 0.03 & 0.00 & 0.12 & 0.11 & 0.09 & 0.00 \\
\hline As & 18.20 & 17.84 & 18.21 & 18.06 & 17.61 & 17.10 & 17.25 & 17.38 & 16.01 & 12.72 & 9.17 \\
\hline $\mathrm{Sb}$ & 3.24 & 3.67 & 3.60 & 3.90 & 4.24 & 4.62 & 4.83 & 4.83 & 5.80 & 10.73 & 15.43 \\
\hline$S$ & 27.61 & 27.47 & 27.78 & 27.67 & 27.03 & 27.17 & 27.38 & 27.31 & 26.82 & 26.64 & 25.78 \\
\hline$\sum w t . \%$ & 99.37 & 99.88 & 100.02 & 100.25 & 98.25 & 98.60 & 99.39 & 99.80 & 98.37 & 99.45 & 97.79 \\
\hline \multicolumn{12}{|c|}{ empirický vzorec (prepočet na 29 atómov) } \\
\hline $\mathrm{Cu}_{\text {Apos. }}$ & 6.000 & 6.000 & 6.000 & 6.000 & 6.000 & 6.000 & 6.000 & 6.000 & 6.000 & 6.000 & 6.000 \\
\hline $\mathrm{Cu}_{\text {Bpos. }}$ & 3.974 & 4.033 & 3.892 & 4.026 & 3.886 & 4.017 & 3.995 & 3.995 & 4.125 & 4.115 & 4.032 \\
\hline $\mathrm{Ag}$ & 0.001 & 0.002 & 0.004 & 0.001 & 0.005 & 0.010 & 0.016 & 0.006 & 0.006 & 0.004 & 0.018 \\
\hline$\Sigma B$ & 3.975 & 4.035 & 3.896 & 4.028 & 3.890 & 4.027 & 4.011 & 4.001 & 4.132 & 4.119 & 4.049 \\
\hline $\mathrm{Mn}$ & 0.020 & 0.006 & 0.014 & 0.016 & 0.022 & 0.019 & 0.015 & 0.006 & 0.021 & 0.015 & 0.012 \\
\hline $\mathrm{Fe}$ & 1.898 & 1.920 & 1.383 & 1.539 & 1.480 & 1.839 & 1.796 & 1.256 & 1.213 & 1.459 & 1.227 \\
\hline $\mathrm{Zn}$ & 0.176 & 0.202 & 0.683 & 0.468 & 0.599 & 0.193 & 0.221 & 0.773 & 0.755 & 0.559 & 0.798 \\
\hline $\mathrm{Cd}$ & 0.000 & 0.003 & 0.005 & 0.000 & 0.006 & 0.000 & 0.000 & 0.003 & 0.000 & 0.000 & 0.000 \\
\hline $\mathrm{Hg}$ & 0.001 & 0.000 & 0.003 & 0.003 & 0.006 & 0.004 & 0.004 & 0.000 & 0.002 & 0.000 & 0.002 \\
\hline $\mathrm{Pb}$ & 0.003 & 0.011 & 0.003 & 0.000 & 0.001 & 0.002 & 0.000 & 0.009 & 0.008 & 0.007 & 0.000 \\
\hline$\Sigma C$ & 2.097 & 2.141 & 2.091 & 2.025 & 2.115 & 2.057 & 2.036 & 2.047 & 1.999 & 2.039 & 2.039 \\
\hline As & 3.637 & 3.561 & 3.630 & 3.596 & 3.589 & 3.467 & 3.473 & 3.500 & 3.283 & 2.626 & 1.965 \\
\hline $\mathrm{Sb}$ & 0.398 & 0.451 & 0.442 & 0.478 & 0.532 & 0.577 & 0.599 & 0.599 & 0.731 & 1.363 & 2.035 \\
\hline$\Sigma D$ & 4.036 & 4.012 & 4.072 & 4.074 & 4.121 & 4.044 & 4.072 & 4.098 & 4.014 & 3.989 & 4.000 \\
\hline$S_{\text {Ypoz. }}$ & 12.000 & 12.000 & 12.000 & 12.000 & 12.000 & 12.000 & 12.000 & 12.000 & 12.000 & 12.000 & 12.000 \\
\hline$S_{\text {zpoz. }}$ & 0.892 & 0.811 & 0.942 & 0.873 & 0.874 & 0.873 & 0.881 & 0.854 & 0.855 & 0.853 & 0.912 \\
\hline vac. & 0.108 & 0.189 & 0.058 & 0.127 & 0.126 & 0.127 & 0.119 & 0.146 & 0.145 & 0.147 & 0.088 \\
\hline$\Sigma Z$ & 1.000 & 1.000 & 1.000 & 1.000 & 1.000 & 1.000 & 1.000 & 1.000 & 1.000 & 1.000 & 1.000 \\
\hline $\mathrm{As} / \mathrm{As}+\mathrm{Sb}$ & 0.90 & 0.89 & 0.89 & 0.88 & 0.87 & 0.86 & 0.85 & 0.85 & 0.82 & 0.66 & 0.49 \\
\hline $\mathrm{Sb} / \mathrm{As}+\mathrm{Sb}$ & 0.10 & 0.11 & 0.11 & 0.12 & 0.13 & 0.14 & 0.15 & 0.15 & 0.18 & 0.34 & 0.51 \\
\hline
\end{tabular}
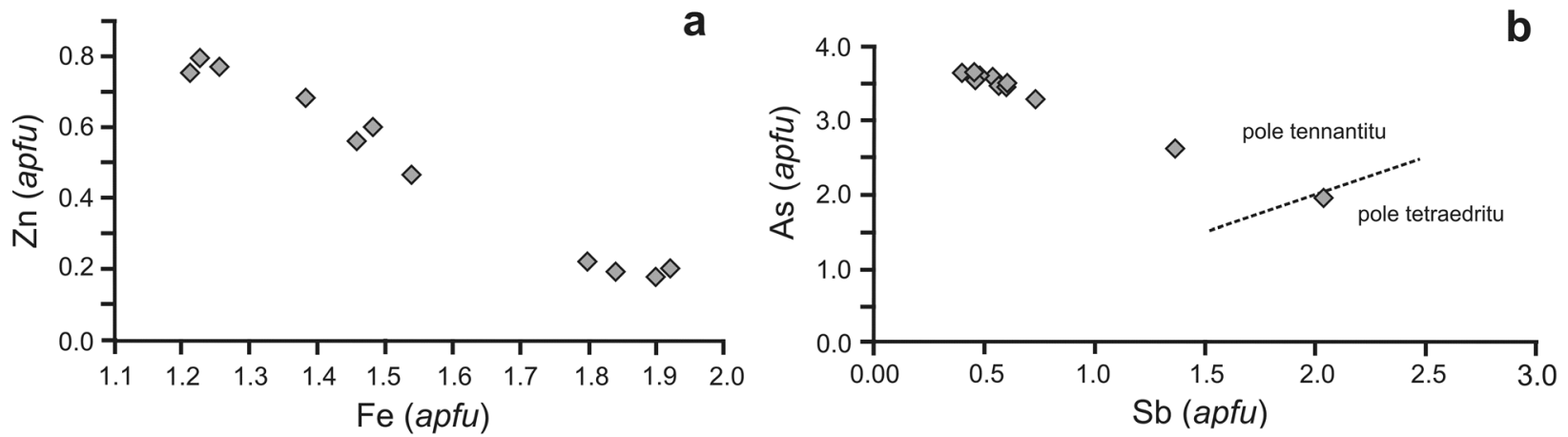

Obr. 8 a) vzájomné zastupovanie Fe vs. Zn a Sb vs. As (obr. b) v mineráloch tetraedritovo-tennantitového radu z Kravan (apfu). 
(pravdepodobne aj Pb-Mo-S minerálu) je zrejmá nielen zo zložitých mikroštruktúrnych vzt’ahov, ale aj z ich chemického zloženia, ktoré je charakteristické výraznou variabilitou (obr. 10a-h; tab. 3). Kvôli zjavnej hydrotermálnej (sčasti aj supergénnej) alterácii bol celkový urán rozpočítaný na $U^{4+}$ a $U^{6+}$ katióny (obr. 10a). Obsah celkového
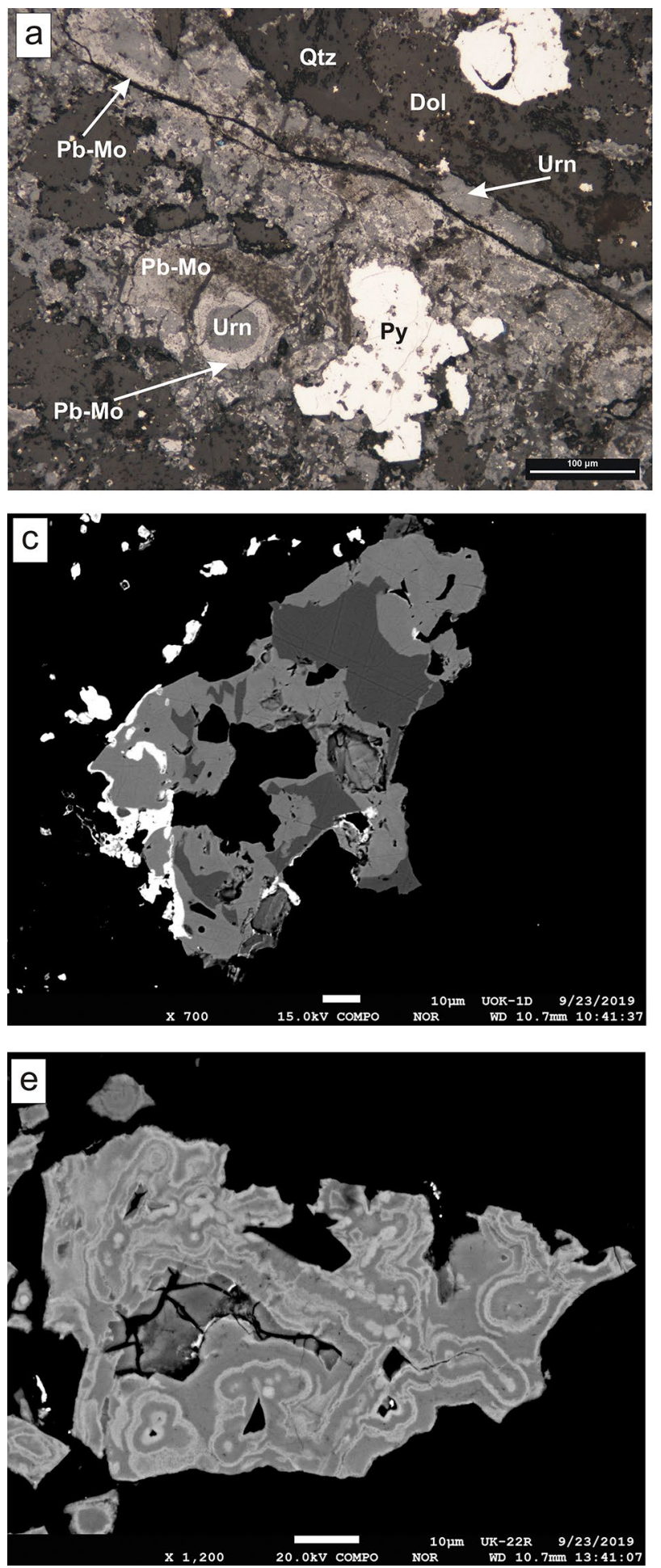

uránu kolíše v rozmedzí $81.90-90.35 \mathrm{hm}$. \% UO $\mathrm{UO}_{2}+\mathrm{UO}_{3}$ (0.68 - 0.82 apfu $\left.U_{\text {Tot }}\right)$. Kolísanie obsahu $U$ v uraninite je však iba v malej miere spôsobené jeho nahrádzaním inými prvkami. Výraznejšiu negatívnu koreláciu vykazuje U iba s Si (0.55 - 3.62 hm. \% SiO ; 0.02 - 0.14 apfu Si; obr. 10c), iba čiastočnú negatívnu koreláciu s uránom vyka-
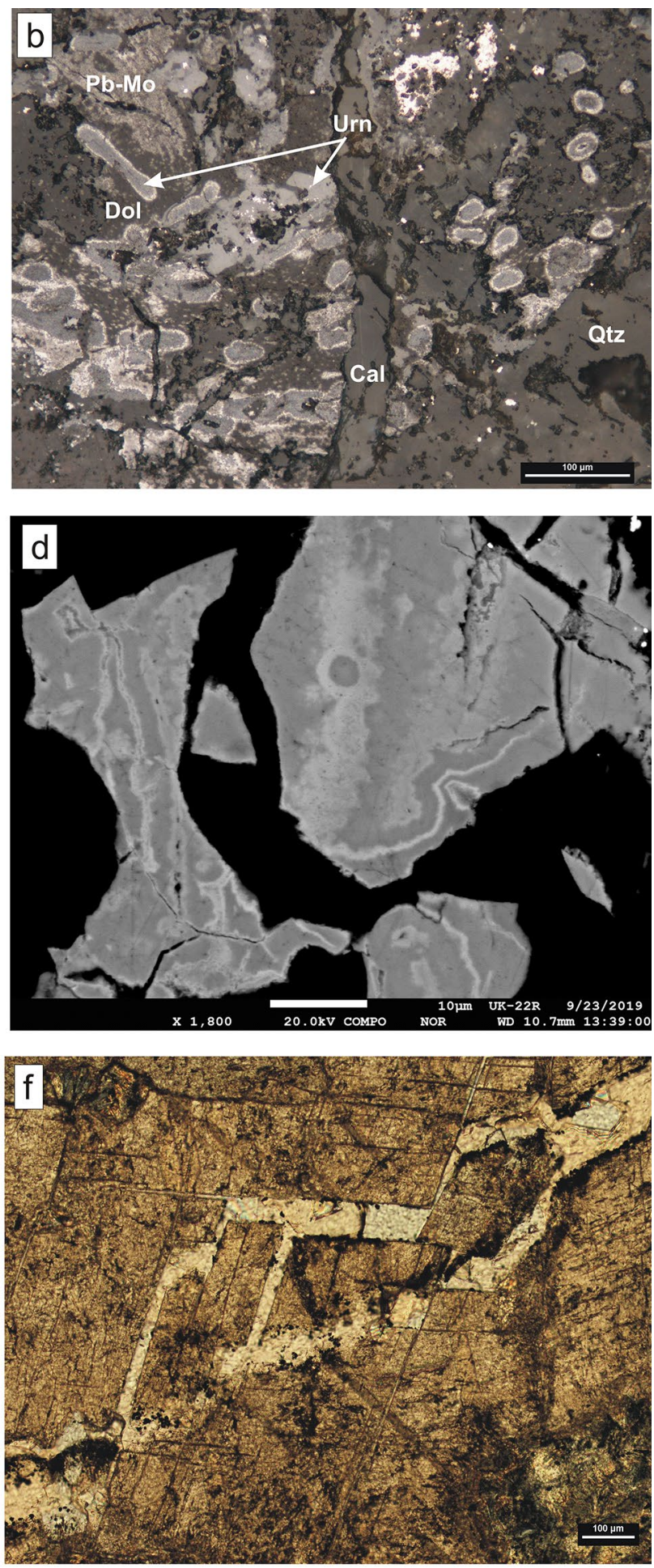

Obr. 9 a) Pyrit (Py) je obrastaný U-Mo mineralizáciou. Uraninit (Urn) sa v žilke prerastá s Pb-Mo-S fázou (Pb-Mo), ale tvorí aj globulárny útvar obrastený touto fázou. Žilovinu tvorí kremeň (Qtz) a dolomit (Dol). b) Zhluk šošoviek tvorený uraninitom (Urn) a Pb-Mo-S minerálnou fázou (svetlejšie zóny šošoviek, resp. označenie Pb-Mo). Oba minerály tvoria aj okolie týchto šošoviek. Staršie žilné minerály reprezentuje kremeň (Qtz) a dolomit (Dol). Celá asociácia je prerážaná kalcitovou žilkou (Cal). c) Chalkopyrit (tmavosivý) obrastaný tennantitom (svetlosivý). Agregát Cu minerálov je prerážaný a lemovaný žilkami coffinitu (biely). d, e) Príklady chemickej zonality Pb-Mo-S minerálnej fázy. f) Dolomit (tmavohnedý) prerážaný žilkami kalcitu (svetlohnedý) po štiepnych trhlinách. Obrázky a, b - odrazené svetlo, PPL, obr. f- prechádzajúce svetlo, XPL (foto: Š. Ferenc). Ostatné obrázky urobené v BSE režime (foto: T. Mikuš). 
Tabul'ka 3 Chemické zloženie uraninitu z Kravan

\begin{tabular}{|c|c|c|c|c|c|c|c|c|c|c|c|c|c|c|}
\hline & 1 & 2 & 3 & 4 & 5 & 6 & 7 & 8 & 9 & 10 & 11 & 12 & 13 & 14 \\
\hline $\mathrm{UO}_{2}{ }^{*}$ & 60.78 & 60.08 & 60.91 & 51.03 & 46.56 & 49.61 & 48.73 & 50.28 & 55.50 & 57.84 & 52.55 & 60.97 & 65.37 & 65.94 \\
\hline $\mathrm{UO}_{3}{ }^{*}$ & 21.47 & 25.28 & 24.59 & 35.60 & 40.09 & 37.19 & 38.21 & 36.69 & 31.69 & 29.55 & 35.37 & 27.63 & 24.27 & 24.41 \\
\hline $\mathrm{CaO}$ & 1.27 & 1.53 & 1.64 & 2.53 & 3.02 & 2.76 & 2.69 & 2.65 & 2.19 & 2.00 & 2.52 & 1.93 & 1.31 & 1.31 \\
\hline $\mathrm{FeO}$ & 0.38 & 0.47 & 0.65 & 0.37 & 0.32 & 0.31 & 0.31 & 0.36 & 0.31 & 0.26 & 0.27 & 0.37 & 0.26 & 0.38 \\
\hline $\mathrm{PbO}$ & 0.49 & 0.53 & 0.45 & 1.79 & 1.81 & 1.59 & 2.10 & 1.47 & 1.65 & 1.45 & 1.50 & 0.54 & 0.95 & 0.96 \\
\hline $\mathrm{Al}_{2} \mathrm{O}_{3}$ & 0.16 & 0.13 & 0.20 & 0.09 & 0.04 & 0.02 & 0.05 & 0.07 & 0.08 & 0.08 & 0.03 & 0.15 & 0.03 & 0.03 \\
\hline $\mathrm{Y}_{2} \mathrm{O}_{3}$ & 0.28 & 0.26 & 0.22 & 0.30 & 0.30 & 0.36 & 0.35 & 0.34 & 0.32 & 0.32 & 0.35 & 0.22 & 0.71 & 0.60 \\
\hline $\mathrm{Ce}_{2} \mathrm{O}_{3}$ & 0.22 & 0.28 & 0.21 & 0.06 & 0.22 & 0.22 & 0.21 & 0.18 & 0.15 & 0.24 & 0.23 & 0.21 & 0.23 & 0.15 \\
\hline $\mathrm{Pr}_{2} \mathrm{O}_{3}$ & 0.34 & 0.38 & 0.29 & 0.30 & 0.29 & 0.26 & 0.33 & 0.36 & 0.27 & 0.32 & 0.33 & 0.32 & 0.30 & 0.27 \\
\hline $\mathrm{Nd}_{2} \mathrm{O}_{3}$ & 0.24 & 0.22 & 0.25 & 0.13 & 0.13 & 0.16 & 0.13 & 0.23 & 0.09 & 0.21 & 0.23 & 0.23 & 0.49 & 0.38 \\
\hline $\mathrm{Sm}_{2} \mathrm{O}_{3}$ & 0.24 & 0.27 & 0.21 & 0.20 & 0.20 & 0.23 & 0.21 & 0.21 & 0.24 & 0.26 & 0.24 & 0.22 & 0.49 & 0.44 \\
\hline $\mathrm{Eu}_{2} \mathrm{O}_{3}$ & 0.36 & 0.28 & 0.36 & 0.34 & 0.31 & 0.31 & 0.27 & 0.32 & 0.32 & 0.35 & 0.35 & 0.33 & 0.43 & 0.41 \\
\hline $\mathrm{Gd}_{2} \mathrm{O}_{3}$ & 0.31 & 0.33 & 0.24 & 0.26 & 0.31 & 0.30 & 0.31 & 0.36 & 0.27 & 0.35 & 0.33 & 0.32 & 0.55 & 0.54 \\
\hline $\mathrm{Tb}_{2} \mathrm{O}_{3}$ & 0.13 & 0.09 & 0.03 & 0.05 & 0.05 & 0.12 & 0.08 & 0.07 & 0.11 & 0.13 & 0.13 & 0.14 & 0.10 & 0.10 \\
\hline $\mathrm{Dy}_{2} \mathrm{O}_{3}$ & 0.10 & 0.14 & 0.06 & 0.08 & 0.03 & 0.14 & 0.11 & 0.13 & 0.04 & 0.06 & 0.03 & 0.06 & 0.28 & 0.23 \\
\hline $\mathrm{Er}_{2} \mathrm{O}_{3}$ & 0.53 & 0.47 & 0.53 & 0.51 & 0.51 & 0.49 & 0.50 & 0.50 & 0.48 & 0.51 & 0.49 & 0.50 & 0.58 & 0.54 \\
\hline $\mathrm{Tm}_{2} \mathrm{O}_{3}$ & 0.10 & 0.16 & 0.09 & 0.13 & 0.06 & 0.11 & 0.05 & 0.11 & 0.11 & 0.09 & 0.15 & 0.14 & 0.17 & 0.15 \\
\hline $\mathrm{Yb}_{2} \mathrm{O}_{3}$ & 0.21 & 0.22 & 0.20 & 0.23 & 0.21 & 0.17 & 0.20 & 0.23 & 0.21 & 0.21 & 0.24 & 0.19 & 0.19 & 0.19 \\
\hline $\mathrm{Lu}_{2} \mathrm{O}_{3}$ & 0.06 & 0.12 & 0.07 & 0.08 & 0.13 & 0.05 & 0.12 & 0.12 & 0.15 & 0.09 & 0.12 & 0.08 & 0.10 & 0.11 \\
\hline $\mathrm{SiO}_{2}$ & 3.62 & 2.51 & 2.30 & 1.40 & 0.68 & 0.68 & 0.78 & 0.98 & 1.09 & 1.16 & 0.83 & 1.88 & 0.56 & 0.57 \\
\hline $\mathrm{P}_{2} \mathrm{O}_{5}$ & 0.04 & 0.04 & 0.03 & 0.10 & 0.11 & 0.08 & 0.07 & 0.08 & 0.08 & 0.07 & 0.08 & 0.03 & 0.03 & 0.02 \\
\hline $\mathrm{As}_{2} \mathrm{O}_{5}$ & 0.65 & 0.51 & 1.65 & 0.87 & 0.90 & 0.88 & 0.74 & 0.92 & 0.78 & 0.80 & 0.66 & 0.77 & 0.67 & 0.63 \\
\hline $\mathrm{SO}_{3}$ & 0.01 & 0.01 & 0.01 & 0.02 & 0.01 & 0.02 & 0.02 & 0.01 & 0.03 & 0.02 & 0.01 & 0.01 & 0.01 & 0.00 \\
\hline
\end{tabular}

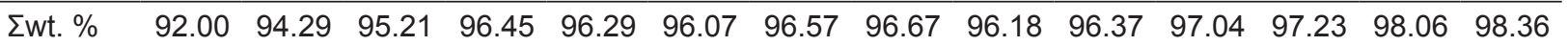
atómové koeficienty (prepočítané na 2 O)

\begin{tabular}{|c|c|c|c|c|c|c|c|c|c|c|c|c|c|c|}
\hline$U^{4+}$ & 0.538 & 0.536 & 0.531 & 0.448 & 0.414 & 0.445 & 0.435 & 0.445 & 0.499 & 0.521 & 0.470 & 0.534 & 0.601 & 0.606 \\
\hline$U^{6+}$ & 0.179 & 0.213 & 0.202 & 0.295 & & 0.315 & 0.322 & & 0.269 & 0.251 & 0.298 & 0.228 & 0.211 & 0.212 \\
\hline$\Sigma U$ & 0.717 & 0.749 & 0.733 & 0.743 & 0.750 & 0.760 & 0.758 & 0.751 & 0.769 & 0.773 & 0.768 & 0.762 & 0.812 & 0.818 \\
\hline $\mathrm{Ca}$ & 0.054 & 0.066 & 0.069 & 0.107 & 0.129 & 0.119 & 0.116 & 0.113 & 0.095 & 0.087 & 0.109 & 0.081 & 0.058 & 0.058 \\
\hline $\mathrm{Fe}$ & 0.013 & 0.016 & 0.021 & 0.012 & 0.011 & 0.011 & 0.010 & 0.012 & 0.010 & 0.009 & 0.009 & 0.012 & 0.009 & 0.013 \\
\hline $\mathrm{Pb}$ & 0.005 & 0.006 & 0.005 & 0.019 & 0.019 & 0.017 & 0.023 & 0.016 & 0.018 & 0.016 & 0.016 & 0.006 & 0.011 & 0.011 \\
\hline$\Sigma \mathrm{M}^{2+}$ & 0.072 & 0.087 & 0.095 & 0.138 & 0.159 & 0.147 & 0.149 & 0.141 & 0.123 & 0.111 & 0.134 & 0.099 & 0.078 & 0.082 \\
\hline$\overline{\mathrm{Al}}$ & 0.008 & 0.006 & 0.009 & 0.004 & 0.002 & 0.001 & 0.002 & 0.003 & 0.004 & 0.004 & 0.001 & 0.007 & 0.002 & 0.001 \\
\hline Y & 0.006 & 0.006 & 0.005 & 0.006 & 0.006 & 0.008 & 0.007 & 0.007 & 0.007 & 0.007 & 0.007 & 0.005 & 0.016 & 0.013 \\
\hline $\mathrm{Ce}$ & 0.003 & 0.004 & 0.003 & 0.001 & 0.003 & 0.003 & 0.003 & 0.003 & 0.002 & 0.004 & 0.003 & 0.003 & 0.003 & 0.002 \\
\hline $\mathrm{Pr}$ & 0.005 & 0.006 & 0.004 & 0.004 & 0.004 & 0.004 & 0.005 & 0.005 & 0.004 & 0.005 & 0.005 & 0.005 & 0.004 & 0.004 \\
\hline $\mathrm{Nd}$ & 0.003 & 0.003 & 0.004 & 0.002 & 0.002 & 0.002 & 0.002 & 0.003 & 0.001 & 0.003 & 0.003 & 0.003 & 0.007 & 0.006 \\
\hline Sm & 0.003 & 0.004 & 0.003 & 0.003 & 0.003 & 0.003 & 0.003 & 0.003 & 0.003 & 0.004 & 0.003 & 0.003 & 0.007 & 0.006 \\
\hline $\mathrm{Eu}$ & 0.005 & 0.004 & 0.005 & 0.005 & 0.004 & 0.004 & 0.004 & 0.004 & 0.004 & 0.005 & 0.005 & 0.004 & 0.006 & 0.006 \\
\hline $\mathrm{Gd}$ & 0.004 & 0.004 & 0.003 & 0.003 & 0.004 & 0.004 & 0.004 & 0.005 & 0.004 & 0.005 & 0.004 & 0.004 & 0.007 & 0.007 \\
\hline $\mathrm{Tb}$ & 0.002 & 0.001 & 0.000 & 0.001 & 0.001 & 0.002 & 0.001 & 0.001 & 0.001 & 0.002 & 0.002 & 0.002 & 0.001 & 0.001 \\
\hline Dy & 0.001 & 0.002 & 0.001 & 0.001 & 0.000 & 0.002 & 0.001 & 0.002 & 0.001 & 0.001 & 0.000 & 0.001 & 0.004 & 0.003 \\
\hline $\mathrm{Er}$ & 0.007 & 0.006 & 0.007 & 0.006 & 0.006 & 0.006 & 0.006 & 0.006 & 0.006 & 0.006 & 0.006 & 0.006 & 0.008 & 0.007 \\
\hline Tm & 0.001 & 0.002 & 0.001 & 0.002 & 0.001 & 0.001 & 0.001 & 0.001 & 0.001 & 0.001 & 0.002 & 0.002 & 0.002 & 0.002 \\
\hline$Y b$ & 0.002 & 0.003 & 0.002 & 0.003 & 0.003 & 0.002 & 0.002 & 0.003 & 0.003 & 0.003 & 0.003 & 0.002 & 0.002 & 0.002 \\
\hline $\mathrm{Lu}$ & 0.001 & 0.001 & 0.001 & 0.001 & 0.002 & 0.001 & 0.002 & 0.001 & 0.002 & 0.001 & 0.002 & 0.001 & 0.001 & 0.001 \\
\hline$\Sigma Y+\mathrm{B}$ & 0.044 & 0.045 & 0.038 & 0.037 & 0.039 & 0.042 & 0.041 & 0.045 & 0.040 & 0.045 & 0.046 & 0.041 & 0.070 & 0.062 \\
\hline $\mathrm{Si}^{4+}$ & 0.144 & 0.100 & 0.090 & 0.055 & 0.027 & 0.027 & 0.031 & 0.039 & 0.044 & 0.047 & 0.033 & 0.074 & 0.023 & 0.024 \\
\hline$P^{5+}$ & 0.001 & 0.001 & 0.001 & 0.004 & 0.004 & 0.003 & 0.002 & 0.003 & 0.003 & 0.002 & 0.003 & 0.001 & 0.001 & 0.001 \\
\hline $\mathrm{As}^{5+}$ & 0.014 & 0.011 & 0.034 & 0.018 & 0.019 & 0.019 & 0.016 & 0.019 & 0.017 & 0.017 & 0.014 & 0.016 & 0.014 & 0.014 \\
\hline$S^{6+}$ & 0.000 & 0.000 & 0.000 & 0.000 & 0.000 & 0.000 & 0.001 & 0.000 & 0.001 & 0.000 & 0.000 & 0.000 & 0.000 & 0.000 \\
\hline$\Sigma T$ & 0.160 & 0.113 & 0.125 & 0.077 & 0.050 & 0.049 & 0.050 & 0.061 & 0.064 & 0.067 & 0.050 & 0.091 & 0.039 & 0.038 \\
\hline $\mathrm{O}$ & 2.000 & 2.000 & 2.000 & 2.000 & 2.000 & 2.000 & 2.000 & 2.000 & 2.000 & 2.000 & 2.000 & 2.000 & 2.000 & 2.000 \\
\hline $\mathrm{U} /(\mathrm{U}+\mathrm{Si})$ & 0.83 & 0.88 & 0.89 & 0.93 & 0.97 & 0.97 & 0.96 & 0.95 & 0.95 & 0.94 & 0.96 & 0.91 & 0.97 & 0.97 \\
\hline
\end{tabular}


zuje $\mathrm{Pb}(0.45$ - 2.10 hm. \% PbO; 0.005 - 0.02 apfu Pb; obr. 10b). Z ostatných zistených prímesí majú $\mathrm{v}$ uraninite najväčší význam $\mathrm{Ca}(0.82$ - 3.02 hm. \% CaO; 0.04 - 0.13 apfu Ca) a Y+REE (2.66 - $4.62 \mathrm{hm}$. \% Y/REE $\mathrm{O}_{3} ; 0.04$ - 0.07 apfu $Y+R E E)$, ktoré majú s U miernu pozitívnu koreláciu (obr. 10e). Z dominantnejších LREE (priemerne $1.70 \mathrm{hm}$. \% LRRE $\mathrm{O}_{3} ; 0.02$ apfu LREE) majú najväčší význam Gd (priem. 0.35 hm. \% $\mathrm{Gd}_{2} \mathrm{O}_{3}$ ), Eu (priem. 0.34 hm. $\% \mathrm{Eu}_{2} \mathrm{O}_{3}$ ) a $\operatorname{Pr}$ (priem. $0.32 \mathrm{hm} . \% \operatorname{Pr}_{2} \mathrm{O}_{3}$ ). Menej sú zastúpené HREE (priem. $1.13 \mathrm{hm}$. \% $\operatorname{HREE}_{2} \mathrm{O}_{3} ; 0.01$ apfu HREE) s absolútne prevažujúcim $\mathrm{Er}\left(0.51 \mathrm{hm} . \% \mathrm{Er}_{2} \mathrm{O}_{3}\right)$. Priemerný obsah $\mathrm{Y}$ je $0.34 \mathrm{hm} . \% \mathrm{Y}_{2} \mathrm{O}_{3}(0.01$ apfu $\mathrm{Y}$ ). $\mathrm{V}$ menšej miere, ale stabilne, sú $v$ uraninite prítomné $\mathrm{Fe}$ (priem. 0.33 hm. \% FeO; 0.01 apfu Fe) a As (priem. 0.79 hm. $\% \mathrm{As}_{2} \mathrm{O}_{5} ; 0.02$ apfu As).

Coffinit vystupuje iba $v$ podradných množstvách, takmer výlučne iba $v$ rámci akumulácií U-Mo mineralizácie (uraninit, $\mathrm{Pb}-\mathrm{Mo}-\mathrm{S}$ minerálna fáza, coffinit), kde je najmladším minerálom (obr. 7d). Ojedinele boli pozoro-
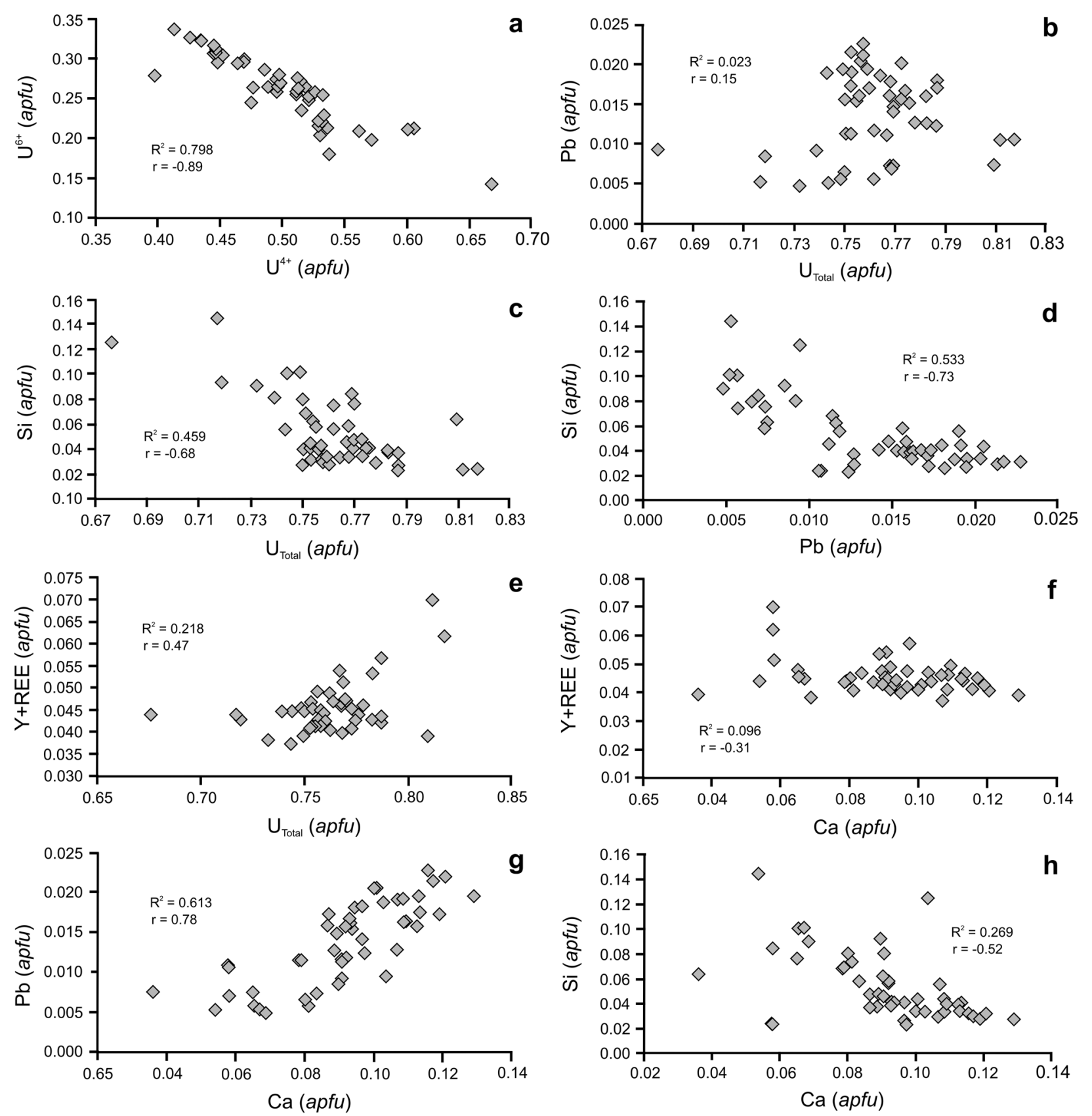

vané chalkopyritovo-tennantitové agregáty $v$ dolomite, pretínané a lemované coffinitom (obr. 9c). Kvôli malým rozmerom coffinitových zŕn bolo jeho zloženie zist'ované iba orientačne (tab. 4). Priemerný empirický vzorec coffinitu (2 WDS analýzy) možno vyjadrit' ako: $\left[\mathrm{U}_{0.82} \mathrm{Ca}_{0.15} \mathrm{Al}_{0.04}\right.$ $\left.(\mathrm{Y}+\mathrm{REE})_{0.01} \mathrm{~K}_{0.01} \mathrm{Mn}_{0.01}\right]_{\Sigma 1.04}\left[\left(\mathrm{SiO}_{4}\right)_{0.93}\left(\mathrm{PO}_{4}\right)_{0.02}\right]_{\Sigma 0.96}$.

Mikroštruktúrne vzt'ahy $\mathrm{Pb}$-Mo-S minerálnej fázy s uraninitom, respektíve s inými minerálmi zrudnenia, sú opísané vyššie (vid' uraninit). Charakteristická je jej extrémna jemnozrnnost'. $V$ odrazenom svetle sa javí pomerne masívny, zriedkavo boli v dolomite zistené aj izolované šupinkovité kryštály s dížkou do $50 \mu \mathrm{m}$. Vzhl'adom sa podobá na molybdenit, má však mierne nižšiu odraznost' a menej výrazné prejavy dvojodrazu, či anizotropie pri skrižených nikoloch.

Chemické zloženie Pb-Mo-S minerálnej fázy je dokumentované v tabul'ke 5. Hlavnými prvkami sú Mo (26.6740.34 hm. \%), Pb (7.34 - 18.82 hm. \%) a S (25.70 - 33.67 $\mathrm{hm}$. \%), menej podstatné sú As (2.36 - $5.59 \mathrm{hm}$. \%) a Fe

Obr. 10 a-h) Vzájomné závislosti prvkov v uraninite (apfu). 
(2.43 - 6.01 hm. \%). Najmenší význam majú Ca $(0.15-$ $2.59 \mathrm{hm}$. \%), Cu (0.15 - $2.61 \mathrm{hm}$. \%), Co (1.44 - 2.95 hm. \%) a Sb (0.80 - 2.94 hm. \%). Obsah C bol potvrdený neštandardizovanou EDS analýzou (vysoký pík uhlíka). Nízke sumy analýz sú zapríčinené jednak prítomnost'ou $\mathrm{CO}_{3}{ }^{2-}$ skupiny a jednak hydratáciou minerálnej fázy. V BSE režime je Pb-Mo-S minerálna fáza zonálna, bud' s nepravidelnou (obr. 9d), alebo s viac-menej pravidelnou prírastkovou zonalitou, ktorá spôsobuje jej krustifikačnú štruktúru (obr. 9e). Svetlejšie zóny (BSE režim) sú bohatšie na $\mathrm{Pb}$, $\mathrm{Sb}$ a As; pre tmavé zóny sú charakteristické Mo, Fe a Co (obr. 11). Distribúcia prvkov je značne nerovnomerná, čomu zodpovedá aj značná variabilita zloženia tejto minerálnej fázy (tab. 5). Vzájomné korelácie prvkov $v$ tejto minerálnej fáze sú uvedené na obrázkoch 12 a 13. Na základe pomeru katiónov a síry je možné vyčlenit' dve skupiny analýz - s vyšším (skupina I) a nižším (skupina II) obsahom S (obr. 12a). Podl'a WDS analýz je možné pre obe skupiny vytvorit' orientačné „idealizované empirické vzorce" (pri dodržaní nulovej nábojovej bilancie medzi aniónmi a katiónmi a pri úvahe, že všetka síra je sulfidická). Skupinu I možno vyjadrit' vzorca-

Tabul'ka 4 Chemické zloženie kravanského coffinitu

\begin{tabular}{|c|c|c|c|}
\hline & 1 & 2 & priemer \\
\hline $\mathrm{UO}_{2}$ & 70.08 & 70.12 & 70.10 \\
\hline $\mathrm{K}_{2} \mathrm{O}^{2}$ & 0.31 & 0.33 & 0.32 \\
\hline $\mathrm{MgO}$ & 0.06 & 0.05 & 0.05 \\
\hline $\mathrm{CaO}$ & 2.66 & 2.63 & 2.65 \\
\hline $\mathrm{MnO}$ & 0.07 & 0.16 & 0.11 \\
\hline $\mathrm{FeO}$ & 0.09 & 0.09 & 0.09 \\
\hline $\mathrm{Al}_{2} \mathrm{O}_{3}$ & 1.25 & 1.05 & 1.15 \\
\hline $\mathrm{Y}_{2} \mathrm{O}_{3}$ & 0.09 & 0.05 & 0.07 \\
\hline $\mathrm{Ce}_{2} \mathrm{O}_{3}$ & 0.23 & 0.20 & 0.22 \\
\hline $\mathrm{Pr}_{2} \mathrm{O}_{3}$ & 0.00 & 0.12 & 0.06 \\
\hline $\mathrm{Nd}_{2} \mathrm{O}_{3}$ & 0.25 & 0.24 & 0.24 \\
\hline $\mathrm{Gd}_{2} \mathrm{O}_{3}$ & 0.08 & 0.06 & 0.07 \\
\hline $\mathrm{Dy}_{2} \mathrm{O}_{3}$ & 0.00 & 0.07 & 0.03 \\
\hline $\mathrm{SiO}_{2}$ & 17.87 & 17.51 & 17.69 \\
\hline $\mathrm{P}_{2} \mathrm{O}_{5}$ & 0.91 & 0.93 & 0.92 \\
\hline $\mathrm{As}_{2} \mathrm{O}_{5}$ & 0.37 & 0.19 & 0.28 \\
\hline$\sum$ wt. \% & 94.31 & 93.78 & 94.05 \\
\hline \multicolumn{4}{|c|}{ atómové koeficienty (prepočet na 2 atómy) } \\
\hline $\mathrm{U}^{4+}$ & 0.819 & 0.830 & 0.824 \\
\hline K & 0.010 & 0.011 & 0.011 \\
\hline $\mathrm{Mg}$ & 0.004 & 0.004 & 0.004 \\
\hline $\mathrm{Ca}$ & 0.150 & 0.150 & 0.150 \\
\hline $\mathrm{Mn}$ & 0.003 & 0.007 & 0.005 \\
\hline $\mathrm{Fe}$ & 0.004 & 0.004 & 0.004 \\
\hline $\mathrm{Al}$ & 0.039 & 0.033 & 0.036 \\
\hline Y & 0.001 & 0.001 & 0.001 \\
\hline $\mathrm{Ce}$ & 0.002 & 0.002 & 0.002 \\
\hline $\operatorname{Pr}$ & 0.000 & 0.001 & 0.001 \\
\hline $\mathrm{Nd}$ & 0.002 & 0.002 & 0.002 \\
\hline $\mathrm{Gd}$ & 0.001 & 0.000 & 0.001 \\
\hline Dy & 0.000 & 0.001 & 0.000 \\
\hline$\Sigma$ Cat. & 1.036 & 1.046 & 1.041 \\
\hline $\mathrm{Si}^{4+}$ & 0.939 & 0.931 & 0.935 \\
\hline $\mathrm{P}^{5+}$ & 0.020 & 0.021 & 0.021 \\
\hline $\mathrm{As}^{5+}$ & 0.005 & 0.003 & 0.004 \\
\hline$\Sigma$ An. & 0.964 & 0.954 & 0.959 \\
\hline U/Si & 0.872 & 0.891 & 0.882 \\
\hline
\end{tabular}

mi: $\mathrm{Mo}_{4}\left(\mathrm{Me}^{2+}\right)_{2}\left(\mathrm{Me}^{3+}\right)_{0.5} \mathrm{~S}_{10}\left[\left(\mathrm{CO}_{3}\right)_{0.5}(\mathrm{OH})_{0.5}\right] \cdot \mathrm{n}\left(\mathrm{H}_{2} \mathrm{O}\right)$, alebo $\mathrm{Mo}_{4}\left(\mathrm{Me}^{2+}\right)_{2}\left(\mathrm{Me}^{3+}\right) \mathrm{S}_{11}\left(\mathrm{CO}_{3}\right)_{0.5} \cdot \mathrm{n}\left(\mathrm{H}_{2} \mathrm{O}\right)$. Skupinu II zase vyjadrujú vzorce: $\mathrm{Mo}_{3}\left(\mathrm{Me}^{2+}\right)_{2}\left(\mathrm{Me}^{3+}\right) \mathrm{S}_{9}\left(\mathrm{CO}_{3}\right)_{0.5} \cdot \mathrm{n}\left(\mathrm{H}_{2} \mathrm{O}\right)$, alebo $\mathrm{Mo}_{4}\left(\mathrm{Me}^{2+}\right)_{3}\left(\mathrm{Me}^{3+}\right) \mathrm{S}_{10}\left[\left(\mathrm{CO}_{3}\right)_{2}(\mathrm{OH})\right]_{\Sigma 3} \cdot \mathrm{n}\left(\mathrm{H}_{2} \mathrm{O}\right)$. Problematika $\mathrm{Pb}-\mathrm{Mo}-\mathrm{S}$ fázy bude d'alej rozvedená $\mathrm{v}$ diskusii.

\section{Nerudná žilná výplň}

Karbonáty (dolomit, kalcit) tvoria podstatnú čast' žilnej výplne. Dolomit bielej až sivobielej farby (niekedy s jemným žltým odtieňom) výrazne prevláda nad kalcitom. Je pomerne hrubokryštalický, s vel'kost'ou kryštálov do $0.5 \mathrm{~cm}$ (priemerne $0.3-5 \mathrm{~mm}$ ). Uzatvára relikty nepravidelných kremenných žiliek aj samostatných zŕn. Kalcit je jemnozrnnejší ako dolomit (kryštály max. do $0.3 \mathrm{~mm}$ ). $\checkmark$ dolomite vytvára žilky hrubé do $0.5 \mathrm{~cm}$ bielej alebo ružovočervenej farby, respektíve aj nepravidelné agregáty (vel'kost' do $3 \times 2 \mathrm{~cm}$ ). Tvorí v ňom výplne puklín po plochách štiepatel'nosti (obr. 9f), alebo zatláča dolomit nepravidelnou siet'ou žiliek. Preráža pyritové žilky, lokálne tiež uzaviera jeho kryštály. Jalové žilky kalcitu prerážajú aj U-Mo-(Cu) zrudnenie. Chemické zloženie karbonátov je pomerne monotónne (tab. 6; obr. 14). V dolomite je okrem hlavných prvkov $(\mathrm{Ca}, \mathrm{Mg})$ stabilne prítomné $\mathrm{Fe}$ (2.31 - 5.42 hm. \% FeO; 0.06 - 0.15 apfu Fe) a Mn (priemerne $2.16 \mathrm{hm}$. \% MnO; 0.06 apfu Mn). V kalcite je najvýznamnejšou prímesou $\mathrm{Mn}$ (priemerne $2.10 \mathrm{hm}$. \% MnO; 0.03 apfu Mn), priemerný obsah $\mathrm{Fe}$ je $0.46 \mathrm{hm}$. \% FeO (0.01 apfu Fe), obsah Mg lokálne dosahuje $2.35 \mathrm{hm}$. \% MgO (0.06 apfu Mg).

Kremeň je oproti karbonátom málo zastúpený. Boli pozorované jeho dve generácie. Kremeň I tvorí alotriomorfné, izolované zrná v dolomite (vel'kost' max. $0.5 \mathrm{~mm}$, žiadna, alebo nevýrazná undulozita), tiež aj relikty nepravidelných agregátov/žiliek (vel'kost' prvé $\mathrm{mm}$ ) uzavieraných dolomitom. Žilky kremeňa II, hrubé okolo $0.1 \mathrm{~mm}$, prerážajú dolomit. Obe generácie kremeňa sú prerážané kalcitovými žilkami.

\section{Diskusia}

\section{Uraninit - jeho datovanie kontra chemické zloženie}

Datovanie uraninitu zo žilnej mineralizácie v Kravanoch pomocou elektrónového mikroanalyzátora (metóda CHIME; Montel et al. 1996), neprinieslo relevantné výsledky. $Z$ tohto dôvodu zistené veky nie sú uvedené v samostatnej tabul'ke, ale iba komentované $v$ rámci diskusie. Získané veky (48 analýz) sa pohybovali vo vel'mi širokom časovom rozsahu (obr. 15): od 195 miliónov rokov (spodná jura) do 46 miliónov rokov (eocén), pri priemere 96 miliónov rokov (začiatok spodnej kriedy). Predpokladaný permský vek uraninitu, na základe geologickej pozície študovanej mineralizácie, teda vôbec nebol potvrdený. $\checkmark$ čom je problém? Množstvo publikovaných prác dokazuje, že uraninit citlivo reaguje na naložené postmineralizačné procesy (Grandstaff 1976; Finch, Ewing 1992; Kotzer, Kyser 1993; Alexandre, Kyser 2005; Timón-Sánchez et al. 2019; Yuan et al. 2019; Corcoran, Simonetti 2020).

Široký diapazón zistených vekov je v prípade uraninitu z Kravan jednoznačne priamym odrazom zjavnej variability chemického zloženia uraninitu (tab. 3; obr. 10). V prvom rade, nevýrazná pozitívna korelácia U vs. $\mathrm{Pb}$ indikuje nerovnováhu medzi pôvodným obsahom uránu $v$ uraninite a dcérskym rádiogénnym olovom (obr. 10b). Na druhej strane možno v tomto obrázku vypozorovat' menej výrazné, prekrývajúce sa dve skupiny analýz s pozitívnou i negatívnou koreláciou. Pozitívna korelá- 
cia $\mathrm{Pb}$ vs. Ca (obr. 10g) zrejme dokazuje ich spoločný vstup do systému $v$ neskorších post- permských hydrotermálnych roztokoch („vstup zvonku“). Obdobnú zmenu chemického zloženia uraninitu konštatujú z U ložísk v Saskatchewane (Kanada) Alexandre a Kyser (2005), pričom zdôrazňujú pribúdanie $\mathrm{Si}$, Ca a Fe na úkor $\mathrm{U}$ a $\mathrm{Pb}$ $v$ jeho mladších generáciách. Negatívna korelácia Si vs. U (obr. 10d) v kravanskom uraninite je zase prejavom kofinitizácie uraninitu, čo je typický jav pri jeho omladzovaní $\checkmark$ redukčných podmienkach (Janeczek, Ewing 1992). Viacero generácií, respektíve kompozičných typov uraninitu, no bez možnosti jednoznačného určenia ich počtu, je viditel'ných aj v prípade študovanej mineralizácie už v odrazenom svetle (rozdielna odraznost', mladšie generácie sú menej odrazné).

Geologická pozícia žilnej U-Mo-(Cu) mineralizácie $\checkmark$ Kravanoch (pretínanie rudných polôh vulkanitmi a obmedzenie mineralizácie striktne na vulkanity; obr. 1B) indikuje permský vek vzniku pôvodného uraninitu (vid' podkapitolu Genéza mineralizácie, nižšie). Jeho pôvodné zloženie bolo pozmenené najpravdepodobnejšie mladšími, alpínskymi hydrotermálnymi roztokmi. Nové, va- riabilné zloženie je hlavnou príčinou neúspechu CHIME datovania. Aj napriek tomu však možno toto datovanie považovat' za nepriamy dôkaz naložených, post-permských tektonotermálnych a hydrotermálnych procesov v hroniku.

\section{Pb-Mo-S fáza}

$\checkmark$ rámci študovanej mineralizácie je bežne rozšírená, vždy v úzkej priestorovej i genetickej asociácii s uraninitom. $V$ oblasti Dúbravy bola obdobná fáza doposial' zistená iba v jednom prípade, na ložisku Švábovce (Rojkovič 1973, 1974) v zrudnenom pieskovci so zuhol'natenými zvyškami rastlín. Neskôr bola zistená v rámci žilnej U-MoCu mineralizácie vo vrtoch pri Matejovciach nad Hornádom v gemeriku (Rojkovič 1996). Na základe dostupnej literatúry, či web-stránok obdobná prírodná fáza nebola zatial' vo svete nikde inde zistená.

Táto minerálna fáza je značne chemicky variabilná (tab. 5), čo sa prejavuje aj na jej zonalite (obr. 11). Porovnanie mikroanalýz uvedených $v$ prácach Rojkoviča (1974, 1996) s analýzami Pb-Mo-S fázy z Kravan ilustruje obrázok 16, z ktorého je zrejmý široký rozsah zmien ob-
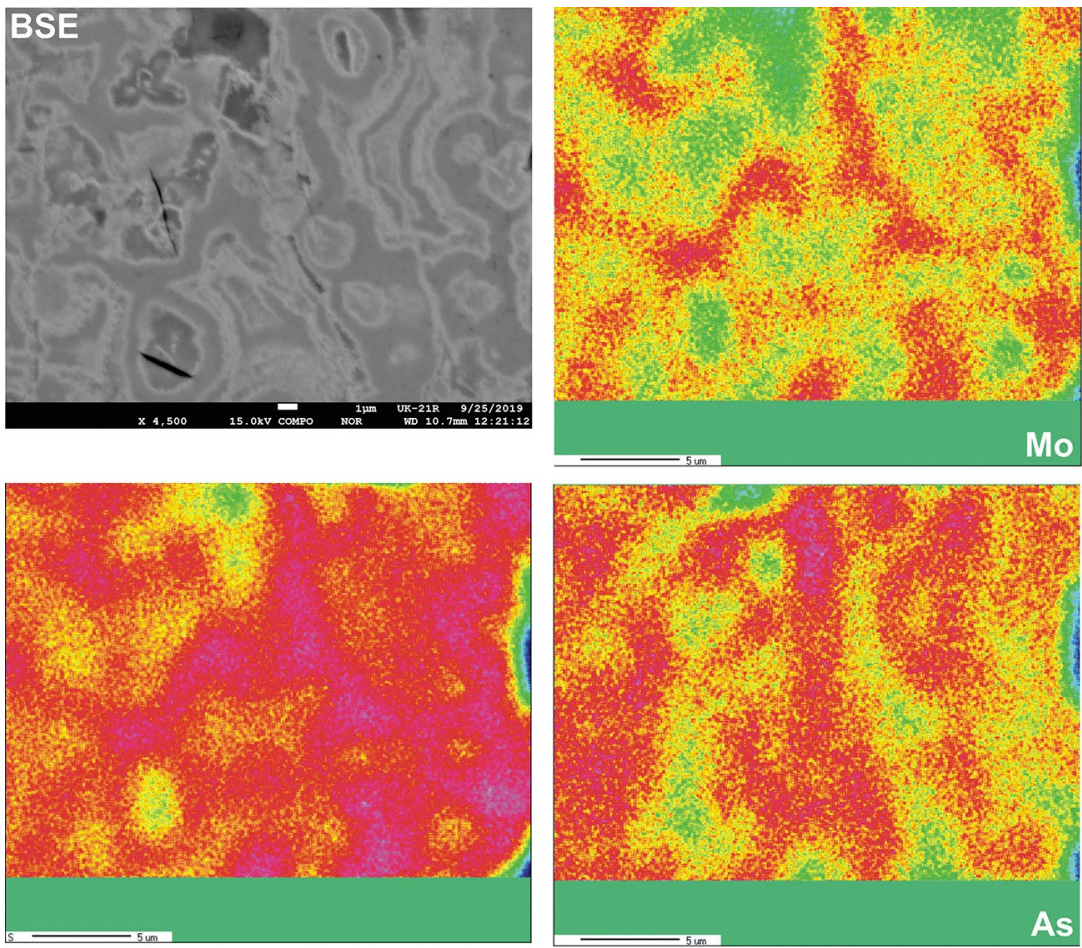

Mo

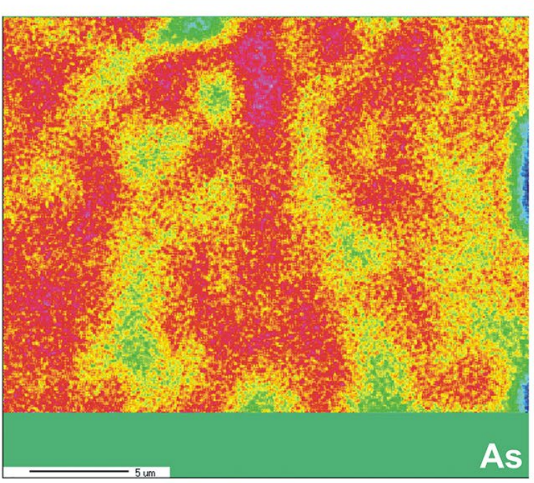

As
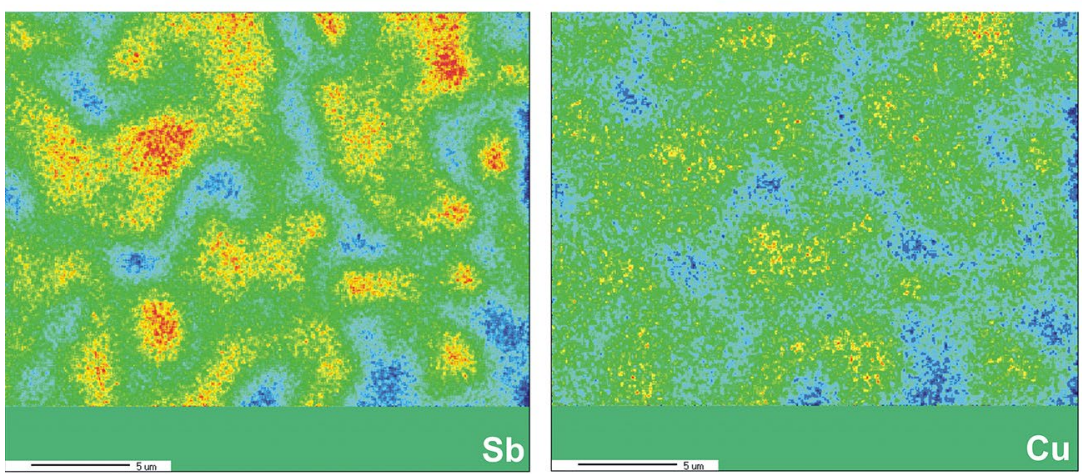
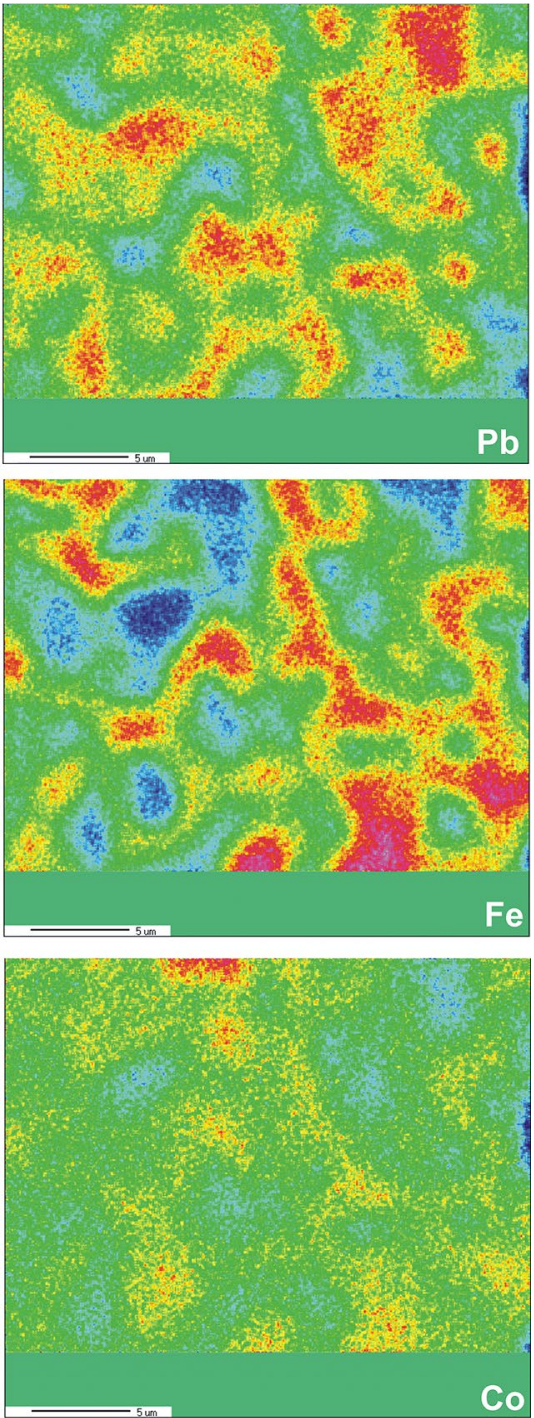

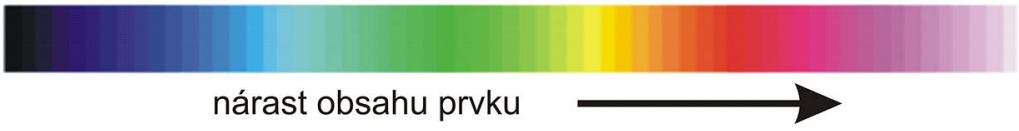

Obr. 11 BSE snímka Pb-Mo-S minerálnej fázy a RTG mapy distribúcie jednotlivých prvkov. Foto: T. Mikuš. 
sahu hlavných prvkov študovanej fázy zo všetkých troch vyššie uvedených lokalít. Rojkovič (1996) predpokladá, že kolomorfné agregáty $\mathrm{Pb}-\mathrm{Mo}-\mathrm{S}$ fázy z Matejoviec $\mathrm{n}$. Hornádom sú tvorené striedaním sa vrstvičiek molybdenitu (resp. jordisitu), galenitu a pyritu. Zaujímavé a trochu kontroverzné je však konštatovanie tohto autora, že RTG difrakčnou analýzou agregátov tejto fázy bol preukázaný iba molybdenit.

Mikroanalýzy fázy z Kravan však prinajmenej nepoukazujú na striedanie sa vrstvičiek molybdenitu a pyritu, vzhl'adom na pozitívnu koreláciu Fe vs. Mo (obr. 13d). Naopak, negatívna korelácia $\mathrm{As}, \mathrm{Sb}, \mathrm{Cu}$ a Pb s molybdénom (obr. 12) môže naznačovat' ich vstup do katiónovej pozície, namiesto Mo. Okrem S sú v aniónovej pozícii určite zastúpené $\mathrm{CO}_{3}{ }^{2-}$ a $\mathrm{OH}^{-}$skupiny, takmer s istotou možno predpokladat' aj prítomnost' vol'nej $\mathrm{H}_{2} \mathrm{O}$. Nejednoznačná je pozícia S, pretože je možné, že jej čast' môže byt' nielen sulfidická, ale aj síranová. Chemické zloženie Pb-Mo -S minerálnej fázy (a značný stupeň vol'nosti pri tvorbe hypotetických empirických vzorcov) naznačuje, že ide najpravdepodobnejšie o do rôznej miery alterovaný molybdenit (resp. jordisit), pravdepodobne kombináciou účinku post-permských hydrotermálnych roztokov a sčasti aj supergénnych procesov, obdobne ako $v$ prípade uraninitu. Mo-Pb-S fáza z Kravan zrejme predstavuje nestechiometrickú prírodnú „chemickú zmes“, s najväčšou pravdepodobnost'ou nejde o nový minerál. Tiež však môže íst' aj o intímne prerastanie dvoch, prípadne viacerých doposial' neidentifikovaných minerálov.

\section{Genéza mineralizácie}

Vulkanické procesy výrazne prispievajú k vzniku vulkanogénnej U-( \pm Mo) mineralizácie. Obdobne aj vulkanické efuzívne horniny a ich pyroklastiká predstavujú významný zdroj U a Mo pre danú mineralizáciu (Nash 2010; Breit, Hall 2011). Najvýznamnejšia a najrozšírenejšia vulkanogénna mineralizácia je spätá s felzickými, kyslými vulkanitmi - ryolitmi (napr. ložisková oblast' kalder McDermitt a Virgin Valley v USA; Castor, Henry 2000, alebo ložisko Smolian v Bulharsku; Dahlkamp 2016).
V slovenskej časti Karpát je najvýznamnejšia stratiformná U-( \pm Mo) mineralizácia $s$ genetickou väzbou na permský ryolitový vulkanizmus známa $v$ Novoveskej Hute a na bimodálny (bazalt-ryolit) vulkanizmus na ložisku Košice - Kurišková (gemerikum, Slovenské Rudohorie), v tatriku (Kálnica, Selec) je tiež zjavný vzt’ah mineralizácie k produktom permského ryolitového vulkanizmu (Rojkovič 1990, 1997; Demko et al. 2012). Chudobná žilná U mineralizácia v Hodruši a Banskej Štiavnici (Štiavnické vrchy) sa vždy nachádza $v$ neogénom granodiorite, alebo $v$ jeho tesnej blízkosti. Jej spojitost' s granodioritom indikuje aj zvýšený obsah Mo v zrudnených štruktúrach (Koděra 1974). So stúpajúcou bázicitou horniny sa mení aj význam $U$ mineralizácie. Menšie rozšírenie i význam má U-( \pm Mo) mineralizácia s genetickou väzbou na kyslé až intermediárne horniny (dacity, andezity). $V$ prípade talianskych ložísk Novazza a Val Vedello sa uvažuje, že podstatná čast' U mohla byt' uvol'nená najpravdepodobnejšie z permských dacitov (Dahlkamp 2016). V Západných Karpatoch je nevýznamná U mineralizácia zistená v ryolitoch a andezitoch-dacitoch na Petrovej Hore pri Krompachoch, žilná/žilníková U mineralizácia sa nachádza v telesách permských metamorfovaných bazaltoidných andezitov-bazaltov v Kuriškovej pri Košiciach (gemerikum, Slovenské rudohorie; Rojkovič 1990, 1997; Demko et al. 2007). Uránová mineralizácia lokalizovaná vyslovene v bázických vulkanických horninách nie je vo svete prakticky známa.

Priemerný obsah Mo a U v niektorých typoch kyslých až bázických hornín uvádza tabul'ka 7, z ktorej je zrejmý pokles priemerného obsahu týchto prvkov vzhl'adom na vzrastajúcu bázicitu horniny. Je to dôsledok inkompatibility uránu a bázickej silikátovej magmy (Cuney 2014). Podl'a všeobecného modelu (Breit, Hall 2011), vulkanogénne typy U-( \pm Mo) mineralizácie vznikajú vel'mi zriedka priamo z magmatických fluíd. Vplyvom magmatického tepla však dôjde k cirkulácii fluíd uvol'nených zo širšieho okolia magmatického hydrotermálneho systému (formačné fluidá). $V$ plytších úrovniach nad magmatickým centrom (resp. v jeho okolí), môže dochádzat' k miešaniu

Tabul'ka 5 Mikroanalýzy Pb-Mo-S minerálnej fázy z Kravan, s ukážkou výpočtu atómových koeficientov na 16 atómov

\begin{tabular}{|c|c|c|c|c|c|c|c|c|c|c|c|c|c|c|}
\hline & 1 & 2 & 3 & 4 & 5 & 6 & 7 & 8 & 9 & 10 & 11 & 12 & 13 & 14 \\
\hline Mo & 38.82 & 28.58 & 39.13 & 39.96 & 38.44 & 40.34 & 28.45 & 28.71 & 34.24 & 28.62 & 27.94 & 28.27 & 30.47 & 26.67 \\
\hline $\mathrm{Ca}$ & .22 & .19 & .23 & & & & & .84 & & 0.50 & & & 0.27 & 2.59 \\
\hline $\mathrm{Fe}$ & .33 & 2.43 & 5.93 & 5.22 & 6.01 & 5.18 & 2.62 & 2.74 & 5.59 & 3.04 & 2.87 & 2.77 & 3.95 & 2.70 \\
\hline Co & .53 & 2.70 & 2.54 & 2.67 & 2.57 & 2.65 & 1.57 & 1.57 & 1.90 & 1.44 & 1.5 & 1.75 & 1.61 & 2.95 \\
\hline $\mathrm{Cu}$ & & & & & & & & & & & & & 2.26 & 1.17 \\
\hline $\mathrm{Pb}$ & 09 & 11.93 & 9.22 & 7.3 & 9.78 & 7.60 & 17.99 & 17.31 & 12.99 & 18.82 & 17.18 & 18.73 & 17.38 & 13.32 \\
\hline As & 36 & .44 & 3.48 & 3.99 & 3.10 & 4.01 & .96 & 5.27 & 5.57 & 5.97 & 5.50 & 5.42 & 6.59 & 4.58 \\
\hline $\mathrm{Sb}$ & & & & & & & & & & 74 & & & & 2.34 \\
\hline$S$ & 33.67 & 29.12 & 33.39 & 33.25 & 33.21 & 33.56 & 27.01 & 26.96 & 30.93 & 27.56 & 26.91 & 27.82 & 29.46 & 25.70 \\
\hline$\Sigma w t . \%$ & 49 & 82.94 & 95.18 & 3.56 & 4.80 & 4.58 & 38.58 & 88.54 & 4.54 & 91.28 & 87.92 & 90.62 & 94.18 & 82.02 \\
\hline \multicolumn{15}{|c|}{ prepočet na základ 16 atómov } \\
\hline Mo & 3.833 & 3.276 & 3.821 & & & & & & & & & & & 3.163 \\
\hline $\mathrm{Ca}$ & 52 & .051 & .053 & .044 & 0.044 & 0.043 & 0.227 & 0.231 & 0.0 & 33 & & 231 & 69 & 0.736 \\
\hline 10 & 905 & 478 & .995 & 0.883 & 1.016 & 0.868 & 0.519 & 0.542 & 0.981 & 0.587 & 0.570 & 0.535 & 0.722 & 0.549 \\
\hline Co & 406 & 0.504 & 0.403 & 0.428 & 0.411 & 0.420 & 0.295 & 0.294 & 0.316 & 0.263 & 0.287 & 0.320 & 0.278 & 0.569 \\
\hline $\mathrm{Cu}$ & 049 & 0.200 & 0.037 & 0.022 & 0.052 & 0.032 & 0.404 & 0.381 & 0.250 & 0.442 & 0.384 & 0.403 & 0.364 & 0.210 \\
\hline $\mathrm{Pb}$ & & 0.633 & 0.417 & 0.335 & 0.445 & 0.343 & 0.960 & 0.922 & 0.614 & 0.980 & 0.919 & 0.974 & 0.857 & 0.732 \\
\hline As & & & 0.436 & & & & 0.732 & 0.777 & & 0.860 & 0.813 & 0.780 & 0.898 & 0.696 \\
\hline $\mathrm{Sb}$ & 089 & 0.217 & 0.078 & 0.062 & 0.089 & 0.065 & 0.258 & 0.266 & 0.125 & 0.243 & 0.266 & 0.232 & 0.185 & 0.218 \\
\hline S & 9.950 & 9.990 & 9.759 & 9.792 & 9.772 & 9.795 & 9.323 & 9.284 & 9.453 & 9.275 & 9.300 & 9.350 & 9.385 & 9.126 \\
\hline
\end{tabular}


magmatických, formačných aj meteorických vôd (Goodell 1985). Takéto hydrotermálne roztoky potom lúhujú U a Mo z okolných, felzických vulkanických hornín, najmä zo sklovitej matrix magmatitov, respektíve z popola vulkanoklastík (Rojkovič 1990; Nash 2010). Následne dochádza $\mathrm{k}$ jeho depozícii na vhodných štruktúrach, pri redukčných podmienkach. Väčšina vulkanogénnej U-( \pm Mo) mineralizácie je teda vzhl'adom na samotný vulkanizmus epigenetická.

Permské bázické vulkanity - tholeiity a ich pyroklas-
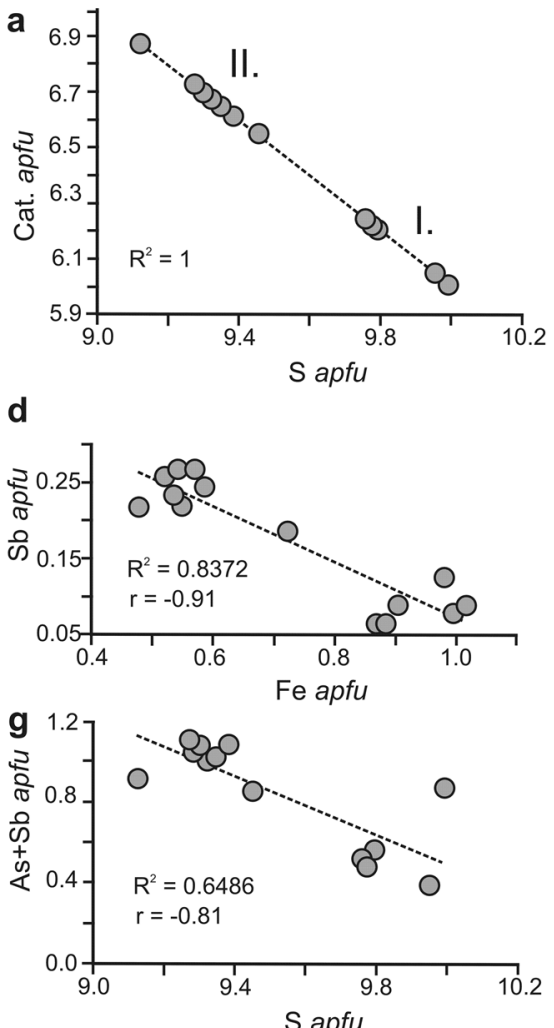

tiká v malužinskom súvrství hronika Západných Karpát nie sú nositel'om U zrudnenia. Mierne zvýšený obsah U (do 100 ppm), bez prejavov samostatnej mineralizácie bol $\vee$ nich zistený pri Sološnici a Lošonci (Malé Karpaty) $v$ asociácii $s$ barytovými žilami s Cu mineralizáciou (Rojkovič 1997). Významnejší a geneticky zaujímavejší výskyt žilnej U-Mo-Cu mineralizácie, ktorému je venovaný tento príspevok, bol zistený $v$ dajkách permských dioritových porfyritov, respektíve bazaltoidných andezitov, pretínajúcich klastické sedimenty malužinského súvrst-
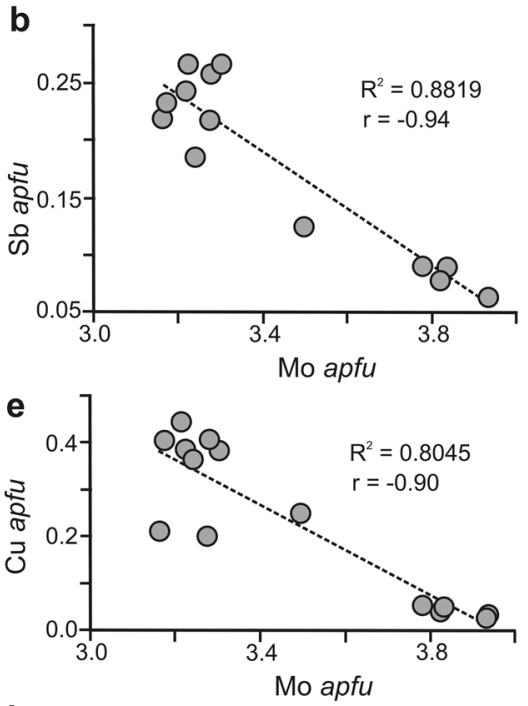

C

h
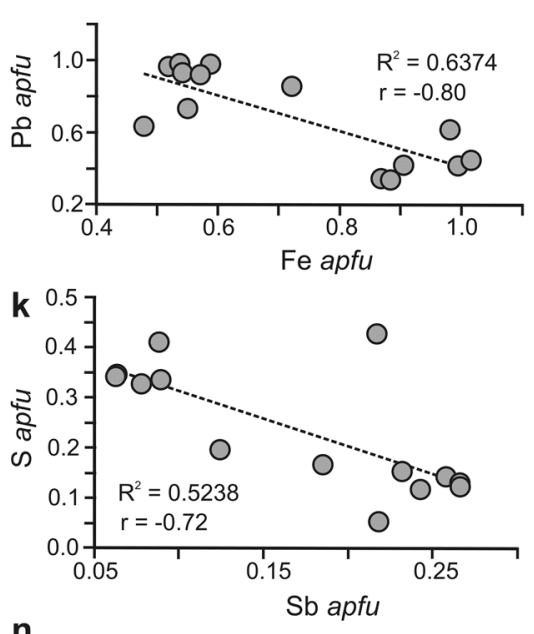

n

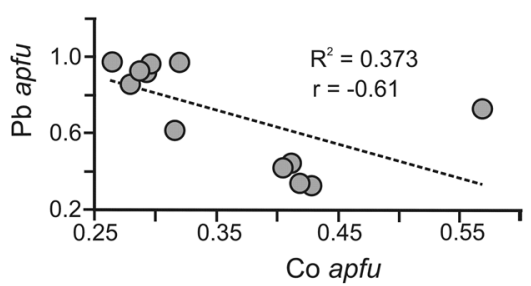

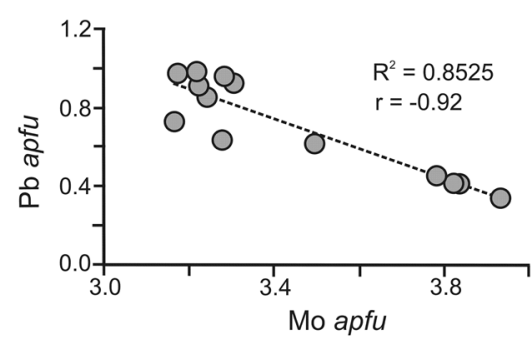
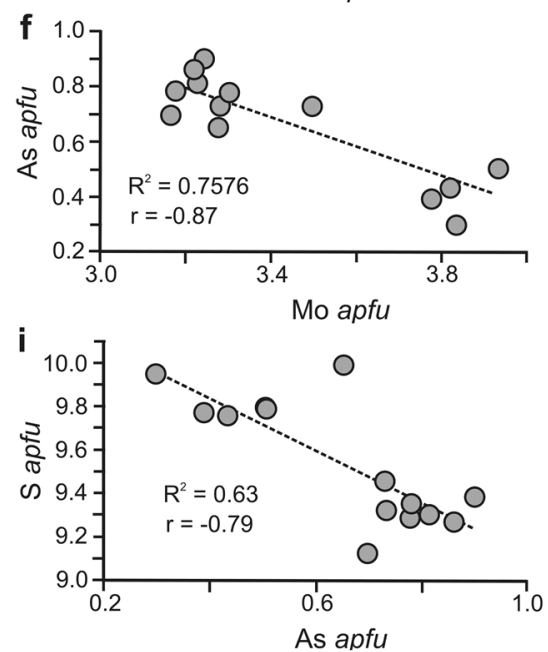

I
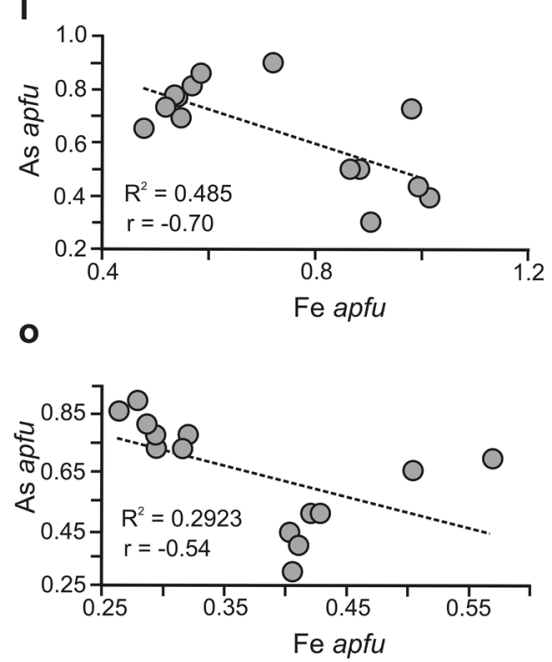

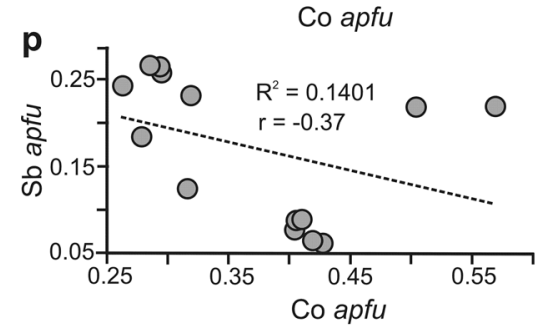

Obr. 12 Záporné vzájomné závislosti prvkov v Pb-Mo-S minerálnej fáze (apfu), pri použití empirického vzorca prepočitaného na základ 16 atómov. 
via pri Kravanoch (Ferenc 2002). Hoci priemerný obsah U v intermediárnych až bázickych vulkanických horninách je všeobecne nízky (tab. 7), boli v nich miestami zistené koncentrácie $U$ vysoko presahujúce 1000 ppm (Bin et al. 2015; Wang et al. 2019 a množstvo iných prác; vid' databázu Georoc). Napriek týmto (relatívne zriedkavým) vysokým hodnotám, nemožno vulkanické horniny na študovanej lokalite považovat' za zdroj U respektíve Mo pre žilnú mineralizáciu. Obdobné žilné horniny vystupujú v rámci mladopaleozoickej ipoltickej skupiny hronika na viacerých miestach $\vee$ Západných Karpatoch a nikde podobná mineralizácia, ani zvýšené obsahy $U$, či rádioaktívne anomálie neboli zistené. Jej vznik možno odôvodnit' náhodnou pozíciou dajok dioritových porfyritov až bazaItoidných andezitov priamo $v$ priestore sedimentov, ktoré sú nositel'mi infiltračnej U mineralizácie (obr. 1B). Žilná U-Mo-Cu mineralizácia tak najpravdepodobnejšie vznikla podl'a nasledujúceho scenára:

I.) sedimentácia kravanských vrstiev v permskej riftogénnej panve: vznik polôh arkóz a arkózových pies-

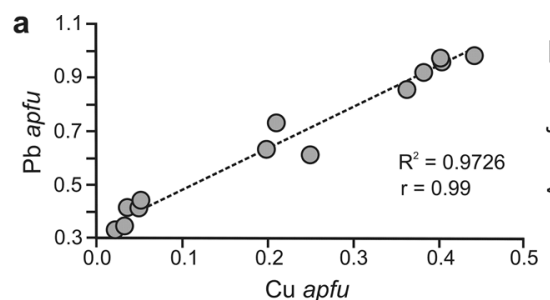

d
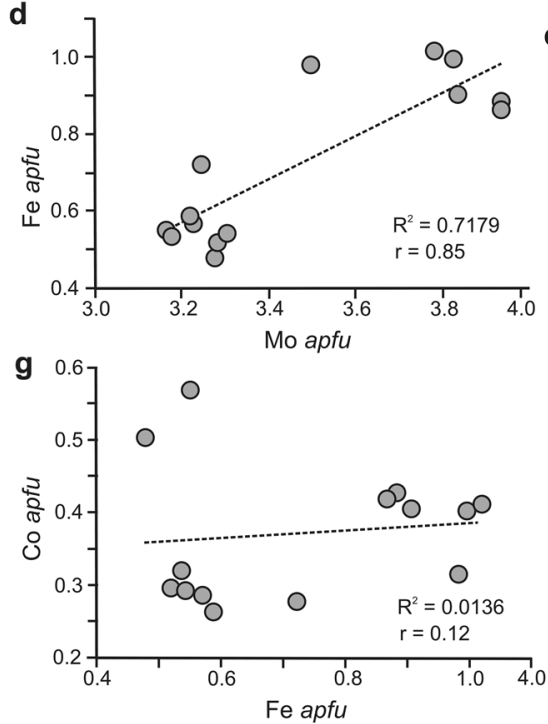
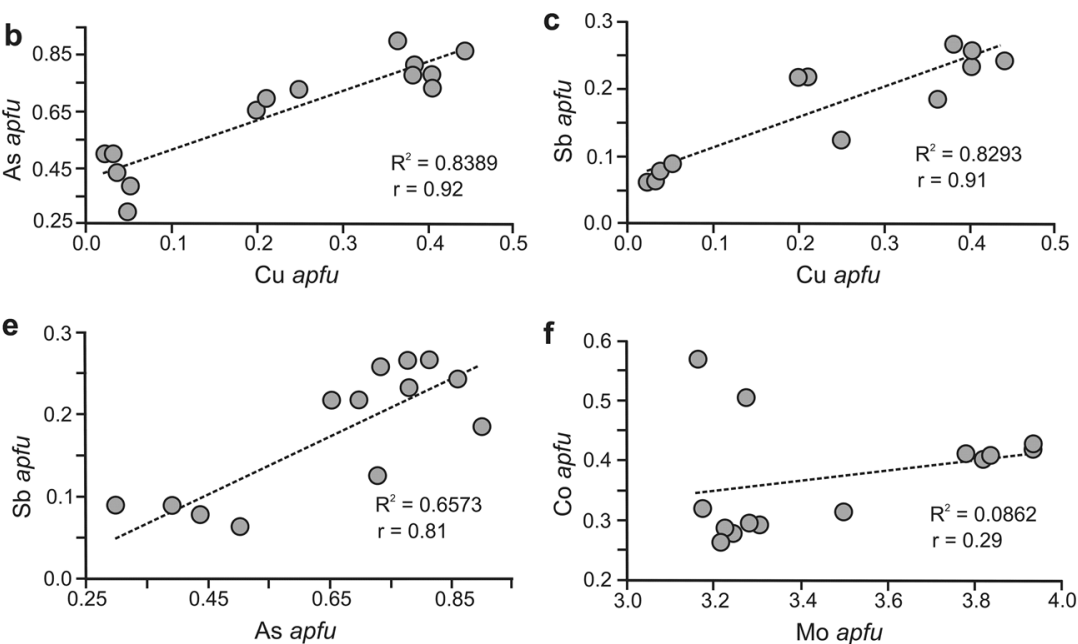

Obr. 13 Kladné vzájomné závislosti prvkov v Pb-Mo-S minerálnej fáze (apfu), pri použití empirického vzorca prepočítaného na základ 16 atómov.

Tabul'ka 6 Chemické zloženie žilného kalcitu (Cal) a dolomitu (Dol) z Kravan

\begin{tabular}{lrrrrrrrrrr}
\hline & 1 & 2 & 3 & 4 & 5 & 6 & 7 & 8 & 9 & 10 \\
\hline $\mathrm{MgO}$ & Dol & Dol & Dol & Dol & Dol & Cal & Cal & Cal & Cal & Cal \\
$\mathrm{CaO}$ & 17.08 & 16.82 & 16.91 & 17.12 & 17.41 & 0.12 & 0.14 & 2.35 & 0.11 & 0.65 \\
$\mathrm{SrO}$ & 30.79 & 29.23 & 31.07 & 29.48 & 29.38 & 53.50 & 52.73 & 50.66 & 54.25 & 53.85 \\
$\mathrm{MnO}$ & 0.00 & 0.01 & 0.00 & 0.00 & 0.00 & 0.03 & 0.04 & 0.03 & 0.02 & 0.05 \\
$\mathrm{FeO}$ & 2.32 & 1.99 & 2.22 & 2.15 & 2.12 & 2.25 & 2.28 & 2.56 & 2.26 & 1.15 \\
$\mathrm{CO}$ & 2.31 & 5.42 & 2.34 & 5.35 & 5.10 & 0.42 & 0.47 & 0.63 & 0.21 & 0.58 \\
\hline$\Sigma$ wt. \% & 45.74 & 45.92 & 45.70 & 46.51 & 46.53 & 44.03 & 43.42 & 44.70 & 44.58 & 44.13 \\
\hline atómové koeficienty, prepočet na & 2 atómy & $($ dolomit) & 1 atóm (kalcit) & & & & & \\
\hline $\mathrm{Mg}$ & 0.847 & 0.828 & 0.838 & 0.833 & 0.845 & 0.003 & 0.004 & 0.062 & 0.003 & 0.017 \\
$\mathrm{Ca}$ & 1.024 & 0.966 & 1.034 & 0.962 & 0.957 & 0.956 & 0.954 & 0.891 & 0.960 & 0.956 \\
$\mathrm{Sr}$ & 0.000 & 0.000 & 0.000 & 0.000 & 0.000 & 0.000 & 0.000 & 0.000 & 0.000 & 0.000 \\
$\mathrm{Mn}$ & 0.065 & 0.056 & 0.063 & 0.060 & 0.059 & 0.034 & 0.035 & 0.038 & 0.034 & 0.017 \\
$\mathrm{Fe}$ & 0.064 & 0.150 & 0.065 & 0.146 & 0.139 & 0.006 & 0.007 & 0.009 & 0.003 & 0.009 \\
\hline $\mathrm{CO}{ }_{3}^{2-}$ & 2.000 & 2.000 & 2.000 & 2.000 & 2.000 & 1.000 & 1.000 & 1.000 & 1.000 & 1.000 \\
\hline $\mathrm{Ca} / \mathrm{Mg}+\mathrm{Ca}+\mathrm{Mn}+\mathrm{Fe}$ & 0.51 & 0.48 & 0.52 & 0.48 & 0.48 & 0.96 & 0.95 & 0.89 & 0.96 & 0.96 \\
$\mathrm{Mg} / \mathrm{Mg}+\mathrm{Ca}+\mathrm{Mn}+\mathrm{Fe}$ & 0.42 & 0.41 & 0.42 & 0.42 & 0.42 & 0.00 & 0.00 & 0.06 & 0.00 & 0.02 \\
$\mathrm{Mn} / \mathrm{Mg}+\mathrm{Ca}+\mathrm{Mn}+\mathrm{Fe}$ & 0.03 & 0.03 & 0.03 & 0.03 & 0.03 & 0.03 & 0.03 & 0.04 & 0.03 & 0.02 \\
$\mathrm{Fe} / \mathrm{Mg}+\mathrm{Ca}+\mathrm{Mn}+\mathrm{Fe}$ & 0.03 & 0.07 & 0.03 & 0.07 & 0.07 & 0.01 & 0.01 & 0.01 & 0.00 & 0.01 \\
\hline
\end{tabular}


kovcov s hojnými úlomkami zuhol'natenej flóry (znos občasnými tokmi z horstva obmedzujúceho panvu),

II.) Vznik infiltračnej U-(Cu) mineralizácie: redukcia a akumulácia $U$ a Mo v sedimentoch bohatých na organickú hmotu,

III.) umiestnenie dajok intermediárnych až bázických vulkanitov: pretínanie polôh na organiku bohatých sedimentov s vysokým obsahom U a Mo, mobilizácia formačných fluíd, čiastočná asimilácia $U$ a Mo do intermediárnej-bázickej magmy,

IV.) chladnutie telies vulkanitov $\rightarrow$ ich kontrakcia (vznik kontrakčných trhlín) $\rightarrow$ vyplnenie kontrakčných trhlín kremeňom, karbonátmi a rudnými minerálmi (kryštalizácia zo zvyškových magmatických roztokov zmiešaných s formačnými vodami okolitých sedimentov).

Obr. 14 Priemety mikroanalýz (apfu) karbonátov žilnej výplne $v$ ternárnych systémoch Mg-Fe-Ca a Mg-Fe-Mn.

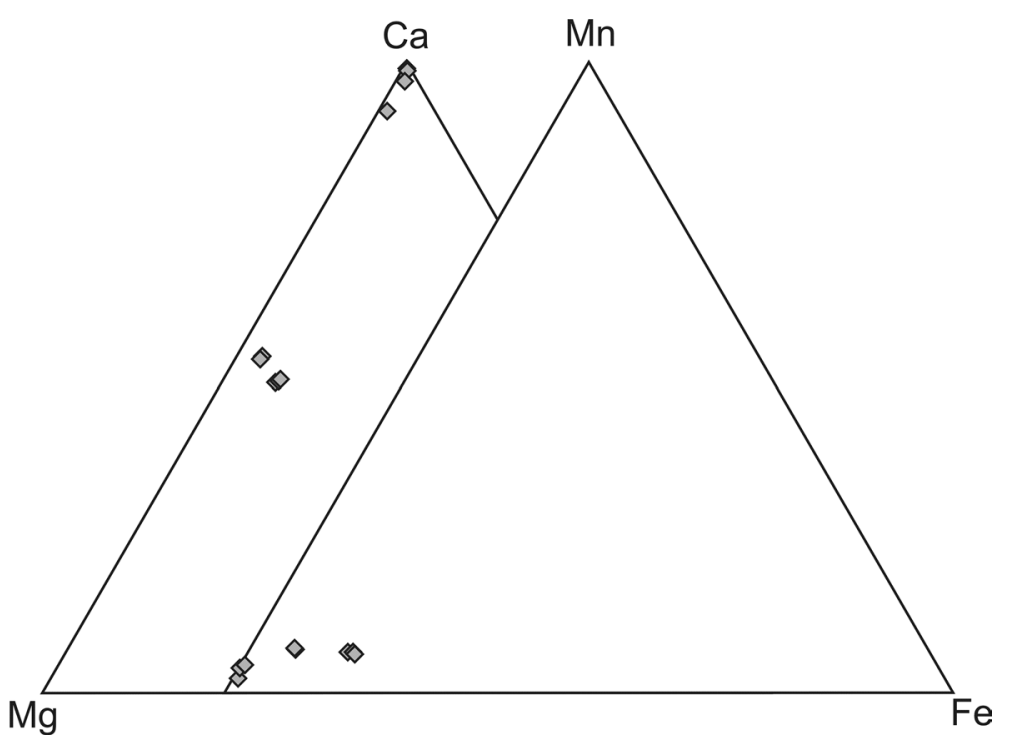

Obr. 15 Histogram vekových údajov zistených metódou CHIME $v$ uraninite žilnej mineralizácie z Kravan.
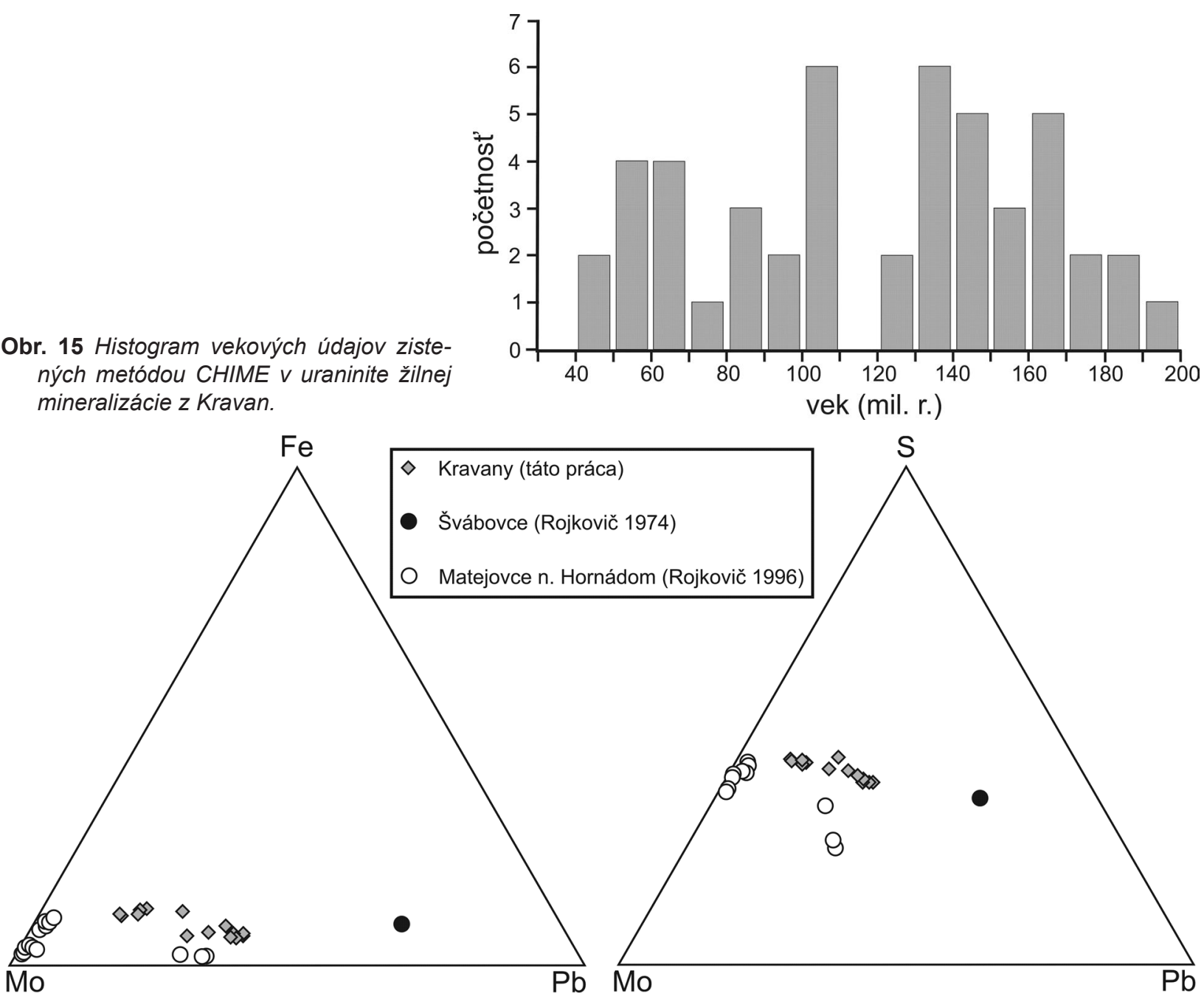

Obr. 16 Priemety mikroanalýz (hm. \%) Pb-Mo-S minerálnej fázy z Kravan, Šváboviec a Matejoviec n. Hornádom v ternárnych diagramoch $\mathrm{Mo}-\mathrm{Pb}-\mathrm{Fe}$ a Mo-Pb-S. 
Tabul'ka 7 Priemerný obsah U a Mo v niektorých typoch hornín

\begin{tabular}{|c|c|c|c|c|c|c|c|c|c|c|c|c|}
\hline I & \multicolumn{4}{|c|}{ kyslé horniny } & \multicolumn{4}{|c|}{ intermediárne horniny } & \multicolumn{4}{|c|}{ bázické horniny } \\
\hline & \multicolumn{2}{|c|}{ kyslé spolu } & \multicolumn{2}{|c|}{ ryolity } & \multicolumn{2}{|c|}{ 'intermed. spolu' } & \multicolumn{2}{|c|}{ andezity } & \multicolumn{2}{|c|}{ báz. spolu } & \multicolumn{2}{|c|}{ tholeiity } \\
\hline & Mo & $U$ & Mo & $\mathrm{U} / \mathrm{U}^{*}$ & Mo & $U / U^{*}$ & Mo & $U / U^{*}$ & Mo & $U$ & Mo & $U / U^{*}$ \\
\hline $\begin{array}{l}\text { Turekian, } \\
\text { Wedepohl (1961) }\end{array}$ & 1.2 & 3 & & & & & & & 1.5 & 1 & & \\
\hline $\begin{array}{l}\text { Makarov (in } \\
\text { Vinogradov 1963) }\end{array}$ & & 3.5 & & & & 1.8 & & & & 0.5 & & \\
\hline Dostal et al. $1976^{x}$ & & & & & & & & 4.5 & & & & $1.3(2)$ \\
\hline Rojkovič (1990)** & & & 4 & 15.9 & & & 1 & 7.6 & & & & \\
\hline Rojkovič (1997)** & & & 7.7 & 9.9 & & & 4.6 & 11.2 & & & 2.7 & 5.9 \\
\hline EarthChem ${ }^{* * *}$ & $\begin{array}{c}4 \\
(102)\end{array}$ & $\begin{array}{c}3.2 \\
(343)\end{array}$ & $\begin{array}{c}5 \\
(77)\end{array}$ & $\begin{array}{c}3.9 \\
(241)\end{array}$ & $\begin{array}{c}1.5 \\
(270)\end{array}$ & $\begin{array}{c}1.5 \\
(1937)\end{array}$ & $\begin{array}{c}1.2 \\
(188)\end{array}$ & $\begin{array}{c}0.9 \\
(1359)\end{array}$ & $\begin{array}{c}0.9 \\
(3888)\end{array}$ & $\begin{array}{c}0.5 \\
(19388)\end{array}$ & $\begin{array}{l}0.5 \\
(438)\end{array}$ & $\begin{array}{c}0.3 \\
(1183)\end{array}$ \\
\hline Georoc*** & & & $\begin{array}{c}2.1 \\
(4251)\end{array}$ & $\begin{array}{l}58.2 / 12.2 \\
0378 / 21990)\end{array}$ & & & $\begin{array}{c}1.8 \\
(1660)\end{array}$ & $\begin{array}{l}179.9 / 6.5 \\
15949 / 11047)\end{array}$ & & & $\left.\begin{array}{c}1.7 \\
(638)\end{array}\right)$ & $\begin{array}{l}201.5 / 0.8 \\
(6431 / 6176\end{array}$ \\
\hline
\end{tabular}

$\mathrm{U}^{*}$ - priemerný obsah $U$ počítaný iba $z$ analýz s obsahom $U<100$ ppm

(120) - čísla v zátvorkách uvádzajú počet analýz z ktorých bola vypočítaná priemerná hodnota obsahu prvku

x-obsah U v matrix vulkanickej horniny

**- vulkanické horniny permu Západných Karpát

*** - z databáz boli použité výlučne analýzy vulkanických hornín

\begin{tabular}{|l|r|r|r|r|r|}
\hline & I. & II. & III. & IV. & V. \\
\hline $\begin{array}{l}\text { kremeň } \\
\text { dolomit }\end{array}$ & & & & & \\
kalcit & & & & & \\
pyrit & - & - & & - & \\
markazit & - & - & & & \\
galenit & & & - & & \\
tetraedrit & & & & & \\
tennantit & & & & & \\
chalkopyrit & & & & & \\
uraninit & & & & & \\
$\begin{array}{l}\text { Pb-Mo-S fáza } \\
\text { coffinit }\end{array}$ & & & & & \\
\hline
\end{tabular}

Obr. 17 Sukcesná schéma žilnej U-Mo-Cu mineralizácie v Kravanoch. Vývojové štádiá: I. kremennopyritové; II. dolomitovo-pyritové; III. medené; IV. uránovo-molybdénové; $V$. kalcitové.

Vek stratiformnej, infiltračnej U-(Cu) mineralizácie v Kravanoch zistený U-Pb datovaním uraninitu je 263 274 miliónov rokov, čo zodpovedá guadalupskej epoche permu (Legierski in Rojkovič, 1997). Podl'a predloženého scenára a geologickej pozície (obr. 1B) sú vulkanické dajky o niečo mladšie ako U-(Cu) mineralizácia (guadalup-loping?). Otvorenou otázkou ostáva, či tieto dajky intrudovali do nespevnených, respektíve čiastočne spevnených klastík, alebo až do úplne litifikovaných hornín. Za zdroj Mo možno tiež považovat' kravanské vrstvy. Rojkovič (1975) na U ložiskách v Kozích chrbtoch, konštatuje jeho zvýšený obsah (do 527 ppm, pri priemernom obsahu 76 ppm) práve v polohách bohatých na organickú hmotu. Zdroj Cu možno hladat' aj v samotných vulkanitoch (sensu Ferenc, Rojkovič 2001).

Do úvahy je potrebné zobrat' aj možnost', že študovaná mineralizácia vznikla $z$ alpínskych hydrotermálnych fluíd, nie v kontrakčných, ale deformačných trhlinách žilných vulkanitov. S touto premisou však možno polemizovat' na základe viacerých faktov. Študovaná mineralizácia je obmedzená výlučne na permské vulkanické horniny. $\checkmark$ prípade, že by $U$ a Mo boli mobilizované z permského stratiformného zrudnenia počas alpínskej orogenézy, tak by tieto prvky migrovali po alpínskych tektonických štruktúrach a precipitovali by $v$ rámci vývoja karbonátových a kremenných žíl aj v okolí, mimo samotného ložiska (nezrudnené pieskovce). Mladšia, alpínska(?) remobilizovaná U mineralizácia (Rojkovič 1997) tvorí žilky rádovo $\mathrm{mm}$ rozmerov; je obmedzená výlučne na relatívne nedeformované rudné šošovky. $V$ prípade ak zlom porušuje rudné šošovky (zónový typ mineralizácie vo v. časti ložiska) je mladšia U mineralizácia opät' obmedzená iba na priestor, v ktorom zlom prechádza cez rudnú šošovku. Mladšie kataklázy minerálov, široká chemická variabilita Pb-Mo-S fázy a uraninitu, tiež jeho „nedatovatel'nost"“, respektíve post-permské zistené veky zapríčinené odnosom $\mathrm{Pb}$ a jeho viacero generácií môžu odrážat' práve naložené, alpínske hydrotermálne a tektonické procesy.

$\mathrm{Na}$ základe uvedeného sa autorský kolektív prikláňa skôr k názoru, že študovaná mineralizácia je s najväčšou pravdepodobnost'ou pôvodne permského veku, s následným alpínskym (najskôr kriedovým) prepracovaním. V zmysle práce Lexa et al. (2007) patrí do neohercýnskeho neskoro- až postorogénneho štádia. Možno ju charakterizovat' ako syngenetickú vulkanogénnu žilnú U-Mo-Cu mineralizáciu. Vývoj žilnej výplne je znázornený na obrázku 17. 


\section{Pod'akovanie}

Tento príspevok mohol vzniknút' vd'aka finančnej podpore grantov VEGA 1/0237/18 a APVV-19-0065, tiež aj projektu ITMS 26210120024, spolufinancovaného zo zdrojov Európskeho fondu regionálneho rozvoja. Autori sú vel'mi vd’ační recenzentom Martinovi Števkovi a Zdeňkovi Dolníčkovi, ktorí svojimi postrehmi a pripomienkami prispeli k skvalitneniu manuskriptu.

\section{Literatúra}

Alexandre P, Kyser TK (2005) Effects of cationic substitutions and alteration in uraninite, and implications for the dating of uranium deposits. Can Mineral 43: 10051017

Biagioni C, George Ll, Cook nJ, Makovicky E, Moëlo Y, Pasero M, Sejkora J, Stanley CJ, Welch MD, Bosi F (2020) The tetrahedrite group: Nomenclature and classification. Am Mineral 105: 109-122

Biely A, BeñušKa P, BezÁk V, Bujnovský A, Halouzka R, IVANIČKA J, KoHÚt M, KLINEC A, LUKÁČIK E, MaglaY J, MIKo O, Pulec M, Putıš M, VozÁr J (1992) Geologická mapa Nízkych Tatier; $1: 50$ 000. GÚDŠ, Bratislava

Biely A, Bezák V, Bujnovský A, Vozárová A, Klinec A, Miko O, Halouzka R, Vozár J, Beñuška P, Hanzel V, Kubeš P, LIŠČÁK P, LUKÁČIK E, MaglaY J, Molák B, PuLEC M, Putıš M, SLAVKAY M (1997) Vysvetlivky ku geologickej mape Nízkych Tatier; 1: 50 000. 1-232, GÚDŠ, Bratislava

Bin YW, CaI NH, Ren CL, Quiang S, Bo LN (2015) Geochronology, geochemistry and geodynamic implications of the Late Mesozoic rocks in the southern Great Xing An Mountains. J Asian Earth Sci 113: 454-470

BReit GN, Hall SM (2011) Deposit model for volcanogenic uranium deposits. U.S. Geological survey, Open -File report

Castor SB, Henry CD (2000) Geology, geochemistry, and origin of volcanic rock-hosted uranium deposits in northwestern Nevada and southeastern Oregon, USA. Ore Geol Rev 16: 1-40

Corcoran L, Simonetti A (2020) Geochronology of uraninite revisited. Minerals 2020, 10, 205; DOI: 10.3390/ $\min 10030205$

CUnEy M (2014) Felsic magmatism and uranium deposits. Bul Soc géol France 185: 75-92

DAHLKAMP FJ (2016) Uranium deposits of the world. Europe. 1-792, Springer-Verlag, Berlin Heidelberg

Demko R, Ferenc Š, Biroñ A, Novotný L, Bartalský B (2012) The genesis of the Kurišková U-Mo ore deposit. Miner Slov 44: 78

Demko R, Ferenc Š, Novotný L, Bartalský B (2007) Geochemicko-petrografické a mineralogické štúdium U-Mo ložiska Košice I - Jahodná. Zbor konf Geochémia 2007 (Bratislava), 106-108. Vyd Dionýza Štúra

Dostal J, CAPEDRI S, Dupuy C (1976) Uranium and potassium in calc-alkaline volcanic rocks from Sardinia. Lithos 9: 179-183

Dostal J, Vozár J, Keppie JD, Hovorka D (2003) Permian volcanism in the Central Western Carpathians (Slovakia): Basin-and-range type rifting in the southern Laurussian margin. Int J Earth Sci (Geol Rundsch) 92: 27-35

EARTHChem. Prístup 24. 9. 2020 na adrese http:// earthchem.org/data/access
FERENC Š (2002) Uranium mineralization in the Permian volcanic rocks at the Kravany, Kozie chrbty Mts., Western Carpathians, Slovac Republic - preliminary results. Proceedings from conference: Uranium Deposits: From their genesis to their environmental aspects, 49-52. Publishing house of Czech Geol Surv, Prague

FERENC Š, Kuruc P (2015) Bane Sv. Alžbety - historický výskyt medených rúd pri Kravanoch (Spiš). Montanrevue 8(4): 6-7

FERENC Š, RoJkovič I (2001) Copper mineralization in the Permian basalts of the Hronicum Unit, Slovakia. Geolines 13: 22-27

FERENC Š, RoJkovič I, MAŤo L' (2003) Uranylové minerály Západných Karpát. Zbor konf Mineralogie Českého masivu a Západních Karpat, 17-23. Univerzita Palackého Olomouc

FINCH RJ, EWING RC (1992) The corrosion of uraninite under oxidizing conditions. J Nuclear Mater 190: 133-156

Fusán O, Bystrický J, Franko O, Chmelík F, IlavskÝ J, KaMENICKÝ L, Kullman E, LUKNIŠ M, MATĚJKA A (1963) Vysvetlivky ku geologickej mape ČSSR (1 : 200 000), list Vysoké Tatry. 1-215, Geofond, Bratislava

Georoc. Prístup 24. 9. 2020 na adrese http://georoc.mpch-mainz.gwdg.de/georoc/Start.asp

Goodel PC (1985) Classification and model of uranium deposit in volcanic environments. Proceedings of a Technical comitee Meeting (El Paso, Texas), 1-16. IAEA Wienna

GRANDSTAFF DE (1976) A kinetic study of the dissolution of uraninite. Econ Geol 71: 1493-1506

JANECZEK J, EWING RC (1992) Dissolution and alteration of uraninite under reducing conditions. J Nuclear Mater 190: $157-173$

KODĚRA M (1974) Mineralógia rádioaktívnych minerálov a ich vzt'ahy k polymetalickej mineralizácii v stredoslovenských neovulkanitoch. MS, archív ŠGúDŠ (Geofond) Eč. 57411

Kotzer TG, KYSER TK (1993) O, U, and Pb isotopic and chemical variations in uraninite: implications for determining the temporal and fluid history of ancient terrains. Am Mineral 78: 1262-1274

Lexa J, Bačo P, Hural V, Chovan M, Koděra P, Petro M, RoJkOVIČ I, TRÉGER M (2007) Vysvetlivky k metalogenetickej mape Slovenskej Republiky. M 1 : 500000. 1-178, ŠGúDŠ, Bratislava

Maglay J, Halouzka R, Bañacký V, Pristaš J, JanočKo J (1999) Neotektonická mapa Slovenska, $1: 500000$. ŠGÚDŠ Bratislava

MAKAROV EC (1963) Geochimija urana v magmatičeskom procese. In Vinogradov AP (ed.) Osnovnye čerty geochimii urana 46-69. AN SSSR Moskva

Montel JM, Foret S, Veschambre M, Nicollet C, Provost A (1996) Electron microprobe dating of monazite. Chem Geol 131: 37-53

NASH JT (2010) Volcanic uranium deposits - geology, geochemical processes, and criteria for resource assessment. U.S. Geological survey, Open-File report

NovotnÝ L, BADÁR J (1971) Stratigrafia, sedimentológia a zrudnenie mladšieho paleozoika severovýchodnej časti Nízkych Tatier. Miner Slov 3: 23-36

OlŠAVSKÝ M, FeRENC Š (2002) Character of Permian volcanosedimentary sequences (Malužiná Formation) of the Hronicum Unit at the NE part of Nízke Tatry Mts. Geol. Carpath., special issue, 53 (only on CD-ROM, 2002), Proceedings of the XVII Congress of Carpathian-Balkan Association, Bratislava, 53/part 0 
RoJKovič I (1973) Mineralogicko-geochemická charakteristika uranovej mineralizácie $v$ perme chočskej jednotky $v$ oblasti Vikartovského chrbta. MS, archív ŠGÚDŠ - Geofond Bratislava Eč. 31507

RoJkovıč I (1974) Mineralogija uranovogo orudenenija v permi chočskoj tektoničeskoj edinicy v oblasti Vikartovskogo chrebta. Geol Zbor Geol Carpath 25: 65-76

RoJkovič I (1975) Geochemical characterization of U-Cu - $\mathrm{Pb}$ mineralization in the Permian of the Choč Nappe in the Vikartovský Chrbát area (Western Carpathians). Geol Zbor Geol Carpath 26: 105-114

RoJkovič I (1990) Ore bearing Permian volcanism in the Western Carpathians. Acta Geol Geogr Univ Comen 45: 71-88

RoJkovıč I (1996) U-Mo-Cu mineralizácia pri Matejovciach nad Hornádom. Miner Slov 28: 491-500

RoJkovıč I (1997) Uranium mineralization in Slovakia. 1-117, Comenius University, Bratislava

RoJkovič I, Francủ J, ČáslaVsKÝ J (1992) Association of organic matter with uranium mineralization in the Permian sandstones of the Western Carpathians. Geol Carpath 43: 27-34

ŠUCHA V, EBERL DD (1992) Postsedimentárna premena sedimentov permu severného gemerika a hronika Západných Karpát. Miner Slov 24: 399-405

Timón-SÁnchez SM, López-Moro FJ, Romer ElRHede D, Fernández-Fernández A, Moro-Benito C (2019) Late -Variscan multistage hydrothermal processes unveiled by chemical ages coupled with compositional and textural uraninite variations in W-Au deposits in the western Spanish Central System Batolith. Geol Acta 17, 1: 1-19
TULIS J, NovotNÝ L (1998): Zhodnotenie geologických prác na $U$ rudy $v$ mladšom paleozoiku hronika $v$ severnej časti Nízkych Tatier a Kozích chrbtov. MS, archív ŠGÚDŠ - Geofond Bratislava Eč. 82752

TUREKIAN KK, WEDEPOHL KH (1961) Distribution of the elements in some major units of the Earth's crust. Geol Soc Amer Bull 72: 175-192

VESELÝ Z, BADÁR J (1984) Malá uranová ložiska v Západních Karpatech. Geol Hydrometal Uran 8: 3-36

VoZÁR J (1977) Magmatické horniny tholeitickej série $\checkmark$ perme chočského príkrovu Západných Karpát. Miner Slov 9: 241-258

VozÁr J, SpIŠIAK J, VozÁrová A, BazArnik J, Král J (2015) Geochemistry and $\mathrm{Sr}$, Nd isotopic composition of the Hronic Upper Paleozoic basic rocks (Western Carpathians, Slovakia). Geol Carpath 66: 3-17

VozÁrovÁ A, VozÁr J (1988) Late Paleozoic in West Carpathians. 1-314, Geol Inst of D. Štúr, Bratislava

Wang F, Xu WL, Xing KC, Tang J, Wang ZW, Sun CY, Wu $W$ (2019) Temporal changes in the subduction of the Paleo-Pacific plate benaeth Eurasia during the Late Mesozoic: Geochronological and geochemical evidence from Cretaceous volcanic rocks in eastern China. Lithos 326-327: 415-434

Yuan F, Jiang SY, LiU J, Zhang S, XiaO Z, LIU G, Hu X (2019) Geochronology and geochemistry of uraninite and coffinite: Insights into ore forming process in the pegmatite-hosted uraniferous province, North Qinling, Central China. Minerals 2019, 9, 552, DOI: 10.3390/ $\min 9090552$ 